Review Article

\title{
Astragalin: A Bioactive Phytochemical with Potential Therapeutic Activities
}

\author{
Ammara Riaz, ${ }^{1}$ Azhar Rasul ${ }^{D},{ }^{1}$ Ghulam Hussain, ${ }^{2}$ Muhammad Kashif Zahoor (D), \\ Farhat Jabeen, ${ }^{1}$ Zinayyera Subhani, ${ }^{3}$ Tahira Younis, ${ }^{1}$ Muhammad Ali, ${ }^{1}$ Iqra Sarfraz, ${ }^{1}$ \\ and Zeliha Selamoglu ${ }^{4}$ \\ ${ }^{1}$ Department of Zoology, Faculty of Life Sciences, Government College University, Faisalabad 38000, Pakistan \\ ${ }^{2}$ Department of Physiology, Faculty of Life Sciences, Government College University, Faisalabad 38000, Pakistan \\ ${ }^{3}$ Department of Biochemistry, University of Agriculture, Faisalabad 38000, Pakistan \\ ${ }^{4}$ Department of Medical Biology, Faculty of Medicine, Nigde Ömer Halisdemir University, Nigde 51240, Turkey
}

Correspondence should be addressed to Azhar Rasul; drazharrasul@gmail.com

Received 8 January 2018; Revised 5 April 2018; Accepted 12 April 2018; Published 2 May 2018

Academic Editor: Paola Patrignani

Copyright ( 2018 Ammara Riaz et al. This is an open access article distributed under the Creative Commons Attribution License, which permits unrestricted use, distribution, and reproduction in any medium, provided the original work is properly cited.

Natural products, an infinite treasure of bioactive chemical entities, persist as an inexhaustible resource for discovery of drugs. This review article intends to emphasize on one of the naturally occurring flavonoids, astragalin (kaempferol 3-glucoside), which is a bioactive constituent of various traditional medicinal plants such as Cuscuta chinensis. This multifaceted compound is well known for its diversified pharmacological applications such as anti-inflammatory, antioxidant, neuroprotective, cardioprotective, antiobesity, antiosteoporotic, anticancer, antiulcer, and antidiabetic properties. It carries out the aforementioned activities by the regulation and modulation of various molecular targets such as transcription factors (NF- $\kappa \mathrm{B}$, TNF- $\alpha$, and TGF- $\beta 1$ ), enzymes (iNOS, COX-2, PGE2, MMP-1, MMP-3, MIP-1 $\alpha$, COX-2, PGE-2, HK2, AChe, SOD, DRP-1, DDH, PLC $\gamma 1$, and GPX), kinases (JNK, MAPK, Akt, ERK, SAPK, I $\kappa \mathrm{B} \alpha$, PI3K, and PKC $\beta 2$ ), cell adhesion proteins (E-cadherin, vimentin PAR-2, and NCam), apoptotic and antiapoptotic proteins (Beclin-1, Bcl-2, Bax, Bcl- $\mathrm{x}_{\mathrm{L}}$, cytochrome c, LC3A/B, caspase-3, caspase-9, procaspase-3, procaspase-8, and IgE), and inflammatory cytokines (SOCS-3, SOCS-5, IL-1 $\beta$, IL-4, IL-6, IL-8, IL-13, MCP-1, CXCL-1, CXCL-2, and IFN- $\gamma$ ). Although researchers have reported multiple pharmacological applications of astragalin in various diseased conditions, further experimental investigations are still mandatory to fully understand its mechanism of action. It is contemplated that astragalin could be subjected to structural optimization to ameliorate its chemical accessibility, to optimize its absorption profiles, and to synthesize its more effective analogues which will ultimately lead towards potent drug candidates.

\section{Introduction}

Medicinal plants have been an infinite source of therapeutic agents since millions of years. Most of the discovered drugs either belong to natural products or derivatives of natural compounds $[1,2]$. The actual fact is that nature is the creator of seemingly limitless series of molecular structures. These structures can serve as unlimited sources for the development of drugs, robust chemotypes, and pharmacophores which are able to be amplified into scaffolds of novel drugs for the cure of various ailments [3]. Before the advent of the postgenomic era with high throughput screening, approximately $80 \%$ of drugs were either pure extracts of medicinal plants or the semisynthetic analogues of various compounds from natural sources [4]. After the second world war, the pharmaceutical research expanded to massive screening of plant extracts in search of new drugs from natural resources [5]. To date, about $61 \%$ of anticancer and $49 \%$ of anti-infective compounds have been discovered from natural products [6].

The term "natural products" encompasses chemical entities derived from plants, bread molds, microorganisms, terrestrial vertebrates as well as invertebrates, and marine organisms [7]. These chemical entities are known to have immense chemical diversity with outstanding drug-like 

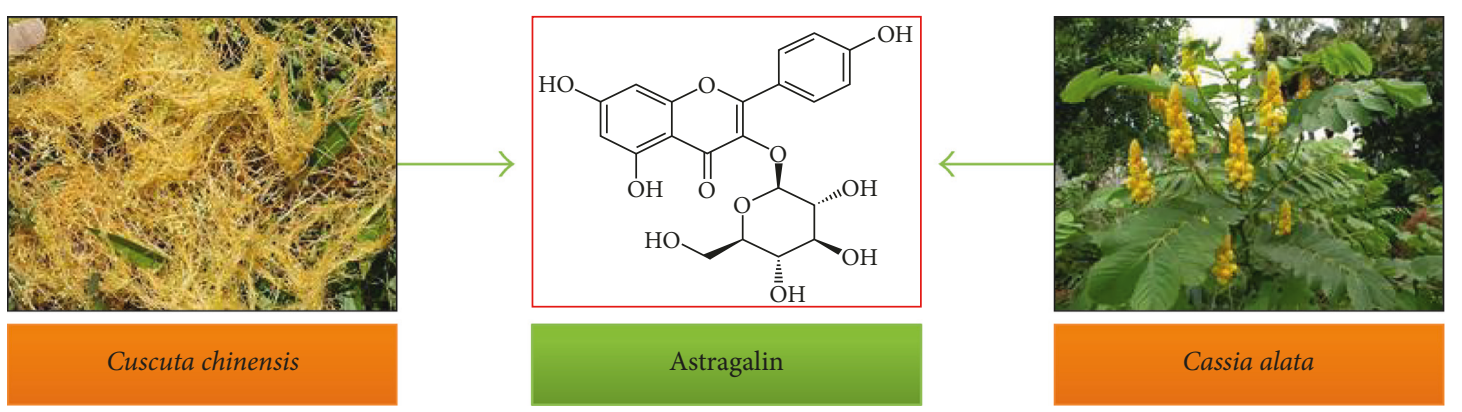

FIgURE 1: Natural sources of astragalin.

properties that contribute towards their multitargeted action [8]. A lot of plant-derived bioactive compounds are used for the cure as well as for the prevention of several diseases. Among these compounds are the polyphenols consisting of alcohols with $\geq 2$ benzene rings and $\geq 1$ hydroxyl group. These polyphenols have a range from simple structural molecules (flavonoids and phenylpropanoids) to highly complex compounds (lignins and melanins). Reports have suggested that polyphenols in general and flavonoids in particular exhibit various biological effects like antiallergic, antibacterial, antiinflammatory, antiviral, antithrombic, hepatoprotective, antibacterial, and antioxidant activities [9].

Flavonoids are structurally diverse and most abundantly found polyphenols in the human diet [10]. They are mostly found in the form of glycosides and acylglycosides. Flavonoids have been divided into various classes such as flavones, flavonols, flavanones, flavanonols, flavanols or catechins, and anthocyanins. They are the essential constituents of our food and are found in onions, parsley, berries including blue berries, black tea, green tea, bananas, red wine, all citrus fruits, sea blackthorns, and dark chocolates with the contents of $70 \%$ or more [11].

Astragalin (kaempferol-3-O- $\beta$-D-glucoside), a bioactive natural flavonoid, has been well known for its medicinal importance. It has been reported to exhibit multiple pharmacological properties including antioxidant $[12,13]$, antiinflammatory [14], anticancer [15], neuroprotective [16], and cardioprotective property [16].

\section{Natural Sources of Astragalin}

Astragalin, a naturally occurring flavonoid, has been identified in a variety of plants (Figure 1 and Table 1 ) such as Cuscuta chinensis Lam., a member of the Convolvulaceae family, which consists of about 60 genera and 1,650 species. The seeds of the genus Cuscuta are a rich source of astragalin and are utilized as a traditional folk medicine to cure osteoporosis in various Asian countries including Pakistan [17]. C. chinensis has high contents of astragalin, that is, 29-34\% of total phenolics as compared to other species [18]. Cassia alata belongs to the family Fabaceae (the largest family among angiosperms) that comprises of $\sim 700$ genera and 20,000 species. The leaves of C. alata are found to be effective against skin diseases including eczema and chronic skin impurities in tropical regions of the world (Malaysia, Brazil, and Indonesia) [19]. Astragalin has also been isolated from the plants of Ebenaceae, Rosaceae, and Eucommiaceae families. The summary of plants containing astragalin, parts utilized, and biological features are enlisted in Table 1.

Astragalin can also be produced in vivo by glycosylation of kaempferol at the 3C-O position [20]. UDP-dependent glycosyltransferases (UGT) were used as biocatalysts in the synthesis of astragalin. A recombinant strain of Arabidopsis thaliana was used to construct an efficient UDP-glucose synthesis pathway by use of enzymes such as uridylyltransferase, sucrose phosphorylase, and sucrose permease. BL21-II was a recombinant strain designed to scale up the production of astragalin by using a fed-batch fermentator.

\section{Biological Activities of Astragalin and Their Mechanisms of Action}

The biologically active and therapeutically effective compound "astragalin" has been known to possess broad spectrum of pharmacological features such as anticancer, anti-inflammatory, antioxidant, neuroprotective, antidiabetic, cardioprotective, antiulcer, and antifibrotic as shown in Figure 2. Various in vivo and in vitro investigations on astragalin have elucidated its medicinal characteristics and mechanism of actions.

3.1. Anti-inflammatory Activity. Inflammation is an immediate response of a body to tissue damage caused by pathogens and toxic stimuli such as physical or chemical injury. Although inflammatory response is a defense mechanism, but if persistent, it can lead to multiple pathological conditions such as cancer, allergy, atherosclerosis, and autoimmune diseases [119]. Negative after effects associated with nonsteroidal type anti-inflammatory drugs (NSAIDs) arouse a need among researchers to find out effective and safe alternatives [120]. Plant extracts enriched with flavonoids have been known to possess antiinflammatory activity [121].

Astragalin, a bioactive natural flavonoid, has been known to mitigate inflammation in LPS-induced murine model of mastitis and lung injury model via reducing the activity of myeloperoxidase and the expression of IL- $1 \beta$, IL-6, and TNF- $\alpha$. Astragalin's anti-inflammatory response proceeds via inhibition of LPS-induced activation of NF- $\kappa \mathrm{B}$, as it is actively involved in alleviating the deterioration of $\mathrm{IkB} \alpha$ and restricting the nuclear translocation of NF- $\kappa \mathrm{B}$ 
TABLE 1: Plants containing astragalin as an important constituent with its biological properties.

\begin{tabular}{|c|c|c|c|c|}
\hline $\begin{array}{l}\text { Name of the plant } \\
\text { Botanical name }\end{array}$ & Common name & $\begin{array}{c}\text { Parts } \\
\text { used/extract }\end{array}$ & Biological activities & References \\
\hline Acer truncatum & Shantung maple & - & - & [21] \\
\hline Aceriphyllum rossii & Mukdenia & Aerial parts & Antioxidant & {$[22]$} \\
\hline Agrimonia pilosa & Hairy agrimony & Aerial parts & $\begin{array}{c}\text { Antihemorrhagic, antiplatelet, antioxidant, and } \\
\text { acetylcholinesterase inhibitory }\end{array}$ & {$[23]$} \\
\hline Allium ursinum & Wild garlic & Flowers & Antimicrobial & {$[24]$} \\
\hline Allium victorialis & Alpine leek & - & Antitumor & {$[25]$} \\
\hline Alsophila spinulosa & Hook tryon & Leaves & Antixanthine oxidase & {$[26]$} \\
\hline Apocynum venetum & Luobuma & Leaves & $\begin{array}{l}\text { Lower blood pressure, antidepressant, } \\
\text { antinephritis, and antineurasthenia }\end{array}$ & {$[27]$} \\
\hline $\begin{array}{l}\text { Jasminum subtriplinerve } \\
\text { Blume }\end{array}$ & - & Aerial parts & 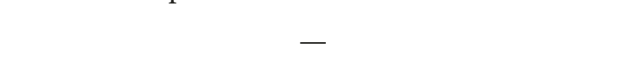 & {$[28]$} \\
\hline Astragalus hamosus & $\begin{array}{l}\text { Dwarf yellow milk } \\
\text { vetch }\end{array}$ & Aerial parts & - & {$[29]$} \\
\hline Caesalpinia decapetala & Mysore thorn & Leaves & - & {$[30]$} \\
\hline Calligonum polygonoides & Phog & Aerial parts & $\begin{array}{c}\text { Antiulcer, anti-inflammatory, hypoglycemic, } \\
\text { and antioxidant }\end{array}$ & {$[31]$} \\
\hline Camellia sinensis & Tea & Leaves and seeds & $\begin{array}{l}\text { Antidysentery, antihyperlipidemia, } \\
\text { antihyperglycemia, and anti-inflammatory }\end{array}$ & {$[32-35]$} \\
\hline Carthamus lanatus L. & Downy safflower & Aerial parts & Antioxidant & {$[35]$} \\
\hline Cassia alata & Ringworm bush & Leaves & Antioxidant, anti-infectious, and DNA repair & [19] \\
\hline Celastrus gemmatus Loes & Chinese bittersweet & Leaves & - & {$[36]$} \\
\hline Centella asiatica & Asiatic pennywort & Leaves & Anti-inflammatory & {$[37]$} \\
\hline Clerodendrum philipinum & Chinese glory bower & Roots & - & {$[38]$} \\
\hline Conyza filaginoides & Laennecia filaginoides & Aerial parts & Antiprotozoal & [39] \\
\hline Corchorus olitorius L. & Moroheiya & Leaves & Inhibits the histamine & {$[40]$} \\
\hline Cuscuta chinensis & Chinese dodder & Seeds & Antiosteoporotic & {$[17,41-43]$} \\
\hline Cuscuta australis & Australian dodder & Seeds & - & {$[17,41-43]$} \\
\hline Diodia teres & Buttonweed & Whole plant & - & [44] \\
\hline Drosera peltata & Sundew & & Antitussive & {$[45]$} \\
\hline Dianthus barbatus cv & Sweet William & Aerial parts & Anti-inflammatory & {$[46]$} \\
\hline Eucommia ulmoides & Hardy rubber tree & Leaves & Antidiabetic, antioxidant, and hypnotic effect & [47-49] \\
\hline Eupatorium cannabinum L. & Hemp agrimony & Aerial parts & - & {$[50]$} \\
\hline Eupatorium lindleyanum & & Aerial parts & - & [51] \\
\hline Exochorda racemosa & Pearlbrush & - & - & {$[52]$} \\
\hline Flaveria bidentis (L.) Kuntze & $\begin{array}{l}\text { Coastal plain yellow } \\
\text { tops }\end{array}$ & Leaves & - & {$[53,54]$} \\
\hline Flos gossypii & - & Flowers & - & {$[55]$} \\
\hline Gladiolus gandavensis & Gladiolus & Aerial parts & - & {$[56]$} \\
\hline Glycyrrhiza glabra & European licorice & Leaves & - & {$[57]$} \\
\hline Glycyrrhiza uralensis Fisch & Chinese licorice & Leaves & - & {$[58]$} \\
\hline Gynura procumbens & Longevity spinach & - & Antidiabetic & [59] \\
\hline Hedera helix & English ivy & - & - & {$[60]$} \\
\hline Helianthemum glomeratum & Island rushrose & Aerial parts & - & {$[61]$} \\
\hline Hemistepta lyrata Bunge & - & Whole plant & - & {$[62]$} \\
\hline Hippophae rhamnoides L. & Sea buckthorn & Leaves & - & {$[63]$} \\
\hline Ipomoea batatas & Sweet potato & Leaf & - & {$[64]$} \\
\hline Koelreuteria paniculata & Golden rain tree & Flowers & Antioxidant & {$[65]$} \\
\hline Allium ampeloprasum & Wild leek & Leaves & Antioxidant & {$[66]$} \\
\hline Ligusticum chuanxiong & - & Aerial parts & - & {$[67]$} \\
\hline Lindera aggregate & Evergreen lindera & Leaves & - & {$[68]$} \\
\hline Litsea coreana & - & Leaves & Antioxidant & [69] \\
\hline Magnolia fargesii & - & Flowers & Anticomplement & [70] \\
\hline Moringa oleifera Lam. & Drumstick tree & Leaves & Antioxidant & [71] \\
\hline Morus alba L. & White mulberry & Leaves & Hypoglycemic and antioxidant & {$[72-78]$} \\
\hline Mussaenda arcuate & Forest star & Leaves & & [79] \\
\hline Nelumbo nucifera & Sacred lotus & Leaves & Lipolytic activity & {$[80-84]$} \\
\hline Ochradenus baccatus & Taily weed & Aerial parts & - & [85] \\
\hline Orostachys japonica & Rock pine & - & Calpain inhibitory activity & {$[86]$} \\
\hline
\end{tabular}


TABle 1: Continued.

\begin{tabular}{|c|c|c|c|c|}
\hline $\begin{array}{l}\text { Name of the plant } \\
\text { Botanical name }\end{array}$ & Common name & $\begin{array}{c}\text { Parts } \\
\text { used/extract }\end{array}$ & Biological activities & References \\
\hline Diospyros kaki & Japanese persimmon & Leaves & $\begin{array}{l}\text { Angiotensin converting enzyme activity, and } \\
\text { inhibition of atopic dermatitis (AD) }\end{array}$ & {$[12,87-89]$} \\
\hline Rosa agrestis & Field briar & Leaves & Anti-inflammatory and antioxidant & {$[13,90-92]$} \\
\hline Peucedanum alsaticum & - & Fruits & - & [93] \\
\hline Phaseolus vulgaris L. & Common bean & & - & {$[94]$} \\
\hline Phlomis spinidens & - & Aerial parts & Antiallergic & {$[95]$} \\
\hline Phyllanthus muellerianus & - & Leaves & Antibacterial and anti-inflammatory & {$[96]$} \\
\hline Polygala cyparissias & - & & Antiulcer & {$[97]$} \\
\hline Polygonum salicifolium & Knotweed & Aerial parts & DPPH-free radical scavenging activity & {$[98]$} \\
\hline Prunus padus L. & European bird cherry & $\begin{array}{l}\text { Flowers and } \\
\text { leaves }\end{array}$ & Antioxidant & [99] \\
\hline Prunus serotina Ehrh & Black cherry & $\begin{array}{l}\text { Leaves and } \\
\text { flowers }\end{array}$ & - & {$[100]$} \\
\hline Pseudotsuga menziesii & Oregon pine & Needles & Cytotoxic & [101] \\
\hline Radix astragali & Milk vetch root & Roots & Antidiabetic & {$[102-104]$} \\
\hline Rhus sylvestris & Sumach & Stems and leaves & Antiosteoporotic & {$[105]$} \\
\hline Rosa soulieana & Shrub rose & Flowers & Antioxidant & {$[106]$} \\
\hline $\begin{array}{l}\text { Rubus rigidus var. } \\
\text { camerunensis }\end{array}$ & Ronce blanche & Aerial parts & Antioxidant & {$[107]$} \\
\hline Sapium sebiferum & Chinese tallow & Leaves & - & {$[108]$} \\
\hline Solenostemma argel & Arghel & Aerial parts & Antibacterial & [109] \\
\hline Solidago canadensis $\mathrm{L}$. & Canada goldenrod & - & Antioxidant & {$[110]$} \\
\hline Sorbus aria (L.) & Lutescens & Leaves & - & [111] \\
\hline Tadehagi triquetrum & - & Whole plant & Antimicrobial and anti-inflammatory & {$[112]$} \\
\hline Tiarella polyphylla & Foam flower & Whole plant & - & {$[113]$} \\
\hline $\begin{array}{l}\text { Trachelospermum } \\
\text { jasminoides }\end{array}$ & Confederate jasmine & Leaves & Antifungal & {$[114]$} \\
\hline Urtica cannabina & - & Fruits & - & [115] \\
\hline Vahlia capensis & - & - & Antibacterial & {$[116]$} \\
\hline Vicia calcarata & Few flowered vetch & Aerial parts & Hepatoprotective & {$[117]$} \\
\hline Wedelia chinensis & - & Whole plant & Inhibitor of the complement system & {$[118]$} \\
\hline
\end{tabular}

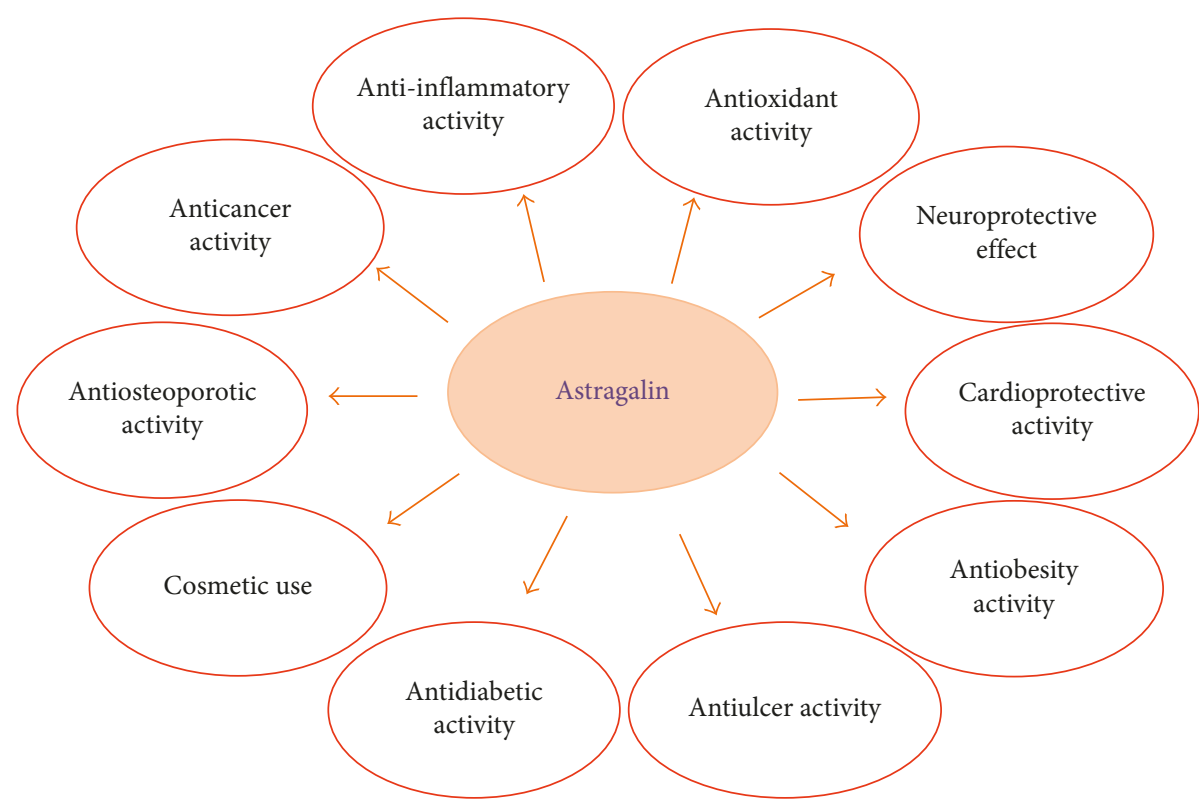

Figure 2: Biological activities of astragalin. 
TABLE 2: Anti-inflammatory activities of astragalin in vitro and in vivo.

\begin{tabular}{|c|c|c|c|c|}
\hline Assay & Organism tested & Dose/concentration & Molecular targets & References \\
\hline LPS-induced mouse mastitis & Mouse mastitis & $\begin{array}{l}10,25 \text {, and } \\
50 \mathrm{mg} / \mathrm{kg}\end{array}$ & $\begin{array}{c}\text { TNF- } \alpha^{\downarrow}, \mathrm{IL}-1 \beta^{\downarrow}, \mathrm{IL}^{\perp} 6^{\downarrow}, \mathrm{p} 65^{\perp} \text {, and } \\
\operatorname{I} \kappa \mathrm{B} \alpha\end{array}$ & {$[92]$} \\
\hline $\begin{array}{l}\text { LPS-induced endotoxemia and } \\
\text { lung injury in mice }\end{array}$ & Mice (lung) & $\begin{array}{l}25,50 \text {, and } \\
75 \mathrm{mg} / \mathrm{kg}\end{array}$ & TNF- $\alpha^{\perp}, \mathrm{IL}-1 \beta^{\perp}$, and IL- $\sigma^{\perp}$ & [122] \\
\hline $\begin{array}{l}\text { LPS-induced macrophages in } \\
\text { mice }\end{array}$ & Mouse cells & $1-100 \mu \mathrm{g} / \mathrm{mL}$ & 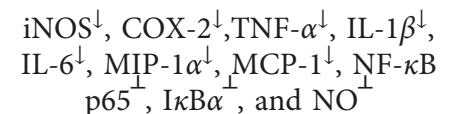 & {$[127]$} \\
\hline LPS-induced RAW 264.7 cells. & Mice (RAW 264.7 cells) & 1,10 , and $100 \mu \mathrm{M}$ & NO $\downarrow$ and TNF- $\alpha \downarrow$ & [37] \\
\hline $\begin{array}{l}\text { Inhibitory activity on the } \\
\text { histamine release by KU812 cells }\end{array}$ & KU812 cells & 10 to $30 \mu \mathrm{mol} / \mathrm{L}$ & $\begin{array}{c}\left.\text { IL- } 4^{\downarrow}, \text { IL-13 } 3^{\downarrow} \text {, and (IFN- } \gamma\right) \text { no } \\
\text { effect }\end{array}$ & {$[12]$} \\
\hline $\begin{array}{l}\text { LPS-induced inflammation in } \\
\text { RAW } 264.7 \text { cells }\end{array}$ & Mice (RAW 264.7 cells) & & $\mathrm{NO}{ }^{\perp}, \mathrm{IL}-6^{\perp}$, and PGE2 ${ }^{\perp}$ & {$[33]$} \\
\hline $\begin{array}{l}P \text {. gingivalis-induced human } \\
\text { gingival epithelial (HGE) cells }\end{array}$ & Human gingival epithelial cells & & $\begin{array}{l}\mathrm{COX}-2^{\perp}, \mathrm{IL}^{\perp} 6^{\perp}, \mathrm{IL}-8^{\perp}, \mathrm{MMP}-1^{\perp} \\
\mathrm{MMP}-3^{\perp}, \mathrm{PGE}-2^{\perp}, \text { and IL- } 4\end{array}$ & {$[125]$} \\
\hline $\begin{array}{l}\text { Anti-inflammatory effects on } \\
\text { Leptospira interrogans-induced } \\
\text { inflammatory response }\end{array}$ & $\begin{array}{l}\text { Uterine and endometrial } \\
\text { epithelial cells of mice }\end{array}$ & $100 \mu \mathrm{g} / \mathrm{mL}$ & 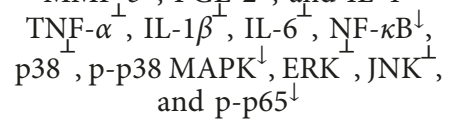 & {$[124]$} \\
\hline $\begin{array}{l}\text { Protective effects against } \\
\text { ovalbumin- (OVA-) induced } \\
\text { allergic inflammation }\end{array}$ & Mouse model of allergic asthma & $\begin{array}{l}0.5 \mathrm{mg} / \mathrm{kg} \text { and } \\
1 \mathrm{mg} / \mathrm{kg}\end{array}$ & SOCS $-3^{\perp}$, SOCS $-5^{\perp}$, and IFN $-\gamma^{\uparrow}$ & {$[126]$} \\
\hline $\begin{array}{l}\text { Alleviation in hepatic fibrosis } \\
\text { function }\end{array}$ & $\begin{array}{l}\text { Diabetic rats and nondiabetic } \\
\text { rats }\end{array}$ & & $\begin{array}{c}\text { PAR2 }{ }^{\perp}, \text { IL- } 1 \beta^{\downarrow}, \text { IL- } 6^{\downarrow}, \text { TNF- } \alpha^{\downarrow} \\
\text { and TGF- } \beta 1^{\perp}\end{array}$ & {$[128]$} \\
\hline Prevention from atopic dermatitis & NC/Nga mice & $1.5 \mathrm{mg} / \mathrm{kg}$ & $\operatorname{IgE}^{\downarrow}$ & [87] \\
\hline
\end{tabular}

${ }^{\top}$ Upregulation; ${ }^{\downarrow}$ downregulation; ${ }^{\perp}$ inhibition.

[92, 122]. Another investigation on LPS-stimulated expression of inflammatory mediators in macrophages has declared the fact that astragalin actively inhibited the expression of proinflammatory mediators via inhibiting NF- $\kappa \mathrm{B}$ signaling pathway [123]. Astragalin has been known to halt the MAPK and NF- $\kappa$ B pathways in leptospira-induced uterine and epithelial inflammation in mice [124]. Astragalin has capability to inhibit the production of prostaglandin E2 (PGE2) in periodontal pathogen-induced periodontitis, a destructive inflammatory pathological condition, in human gingival epithelial cells [125]. Astragalin has been investigated to determine the underlying mechanism for its protective effect against ovalbumin-stimulated allergic reactions in mouse models of allergic asthma. Results have declared that it effectively lowers the eosinophil count in lung tissues and inhibited eosinophilia induced by ovalbumin. As a result, IgE, IL-4, IL-5, and IL-13 were retrieved in bronchoalveolar lavage fluid [126]. Purely prepared astragalin inhibited the activity of PGE2 and downregulated the production of cellular nitrite oxide and IL-6 in LPS-stimulated RAW 264.7 cells [33]. Astragalin treatment leads to the inhibition of alveolar destruction, allergic inflammation, and thickening of airways in the ovalbumin-induced inflammatory mouse model [14]. Anti-inflammatory activities of astragalin in different animal models are recorded in Table 2.

3.2. Antioxidant Activity. In living systems, free radicals such as hydroxyl radicals $(\mathrm{OH} \cdot)$, superoxide anion $\left(\mathrm{O}_{2} \cdot-\right)$, singlet oxygen $\left({ }^{1} \mathrm{O}_{2}\right)$, and ROS are reported to have deleterious impacts on cellular functions. Excessive production of free radicals may affect the balance of prooxidant and antioxidant systems in the body, thus causing various pathological conditions such as arterial hypertension, rheumatism, inflammation, diabetes, cancer, neurodegenerative disorders, and genetic mutations [120]. Researchers have affirmed various plant extracts as natural and infinite treasure of antioxidants. These antioxidants act as free radical scavengers, electron donors, and chelating agents for free catalytic metals in biological systems [75].

Astragalin also inhibits the endotoxin-induced oxidative stress, which can lead to epithelial apoptosis and eosinophilia. It can also act as an antagonizing agent against endotoxin-induced oxidative stress via modulation of LPSTLR signaling network [129]. Astragalin causes the suppression of 6-hydroxydopamine-stimulated neurotoxicity in Caenorhabditis elegans via modulation of apoptosis-related pathways and alleviation of oxidative stress [130]. Astragalin has capability to improve neural function in the ischemia brain injury model of rats via blocking the apoptosis in the hippocampus region by enhancing the expression of NCam [131] (Table 3).

3.3. Neuroprotective Activity. Disturbance in cerebral redox homeostasis is the main cause of neurodegenerative diseases in humans. Cerebral oxidative stress leads to dopaminergic neuronal cell death and dysfunction. Neuroprotective mechanism of naturally occurring bioactive entities is associated with their free radical scavenging capability generated by neurotoxins and oxidative stress-induced processes in neuronal cells of the brain [133].

Astragalin has been reported to decrease the neurodegeneration in $C$. elegans stimulated by 6-OHDA and 
TABLE 3: Antioxidant activity of astragalin in vitro and in vivo.

\begin{tabular}{|c|c|c|c|c|}
\hline Assay & $\begin{array}{l}\text { Organism } \\
\text { tested }\end{array}$ & Dose/concentration & Molecular targets & References \\
\hline Free radical-scavenging activity & & $\begin{array}{c}1,3,10,30,100, \text { or } \\
300 \mu \mathrm{g} / \mathrm{mL}\end{array}$ & & {$[107]$} \\
\hline $\begin{array}{l}\text { Inhibitory activity against autophagy- } \\
\text { associated airway epithelial fibrosis }\end{array}$ & Mice & $1-20 \mu \mathrm{M}$ & $\begin{array}{l}\text { E-cadherin }{ }^{\perp} \text {, vimentin }{ }^{\perp} \text {, Beclin- } 1^{\downarrow}, \\
\text { LC3A/B }\end{array}$ & {$[132]$} \\
\hline Apoptotic and eosinophilia amelioration & $\begin{array}{l}\text { BEAS-2B } \\
\text { cells }\end{array}$ & $1-20 \mu \mathrm{M}$ & $\begin{array}{c}\text { TLR- } 4^{\downarrow}, \text { Eotaxin- } 1^{\downarrow}, \text { PLC } \gamma 1^{\downarrow}, \text { PKC } \beta 2^{\downarrow}, \text { p- } \\
\text { p22 } 2^{\downarrow}, \mathrm{p}^{\downarrow} 47^{\downarrow}, \mathrm{JNK}^{\downarrow}, \mathrm{p} 38 \mathrm{MAPK}^{\downarrow}, \mathrm{Akt}^{\uparrow} \text {, and } \\
\mathrm{ERK}^{\uparrow}\end{array}$ & [129] \\
\hline $\begin{array}{l}\text { Suppression of 6-hydroxydopamine- } \\
\text { induced neurotoxicity in Caenorhabditis } \\
\text { elegans }\end{array}$ & C. elegans & $2.0 \mathrm{mg} / \mathrm{mL}$ & $\begin{array}{c}e g l-1^{\downarrow}, \mathrm{SOD}^{\uparrow}, \mathrm{GPX}^{\uparrow}, \mathrm{AChe}^{\uparrow}, \text { and } \mathrm{p} 38 \\
\mathrm{MAPK}^{\downarrow}\end{array}$ & {$[130]$} \\
\hline $\begin{array}{l}\text { Neuroprotective effect against ischemic } \\
\text { brain injury }\end{array}$ & Wister rats & $5 \mathrm{mg} / \mathrm{kg}$ and $15 \mathrm{mg} / \mathrm{kg}$ & $\mathrm{NCam}^{\uparrow}$ & [131] \\
\hline
\end{tabular}

${ }^{\uparrow}$ Upregulation; ${ }^{\downarrow}$ downregulation; ${ }^{\perp}$ inhibition.

increase lifespan of astragalin-treated nematode. It also reduces the ROS levels, inhibits lipid peroxidation, and increases SOD and GPx activities. Furthermore, it is capable of enhancing $\mathrm{AChE}$ and reducing the transcript level of proapoptotic gene egl-1 associated with neuronal cell death [130]. In another attempt, the effects of astragalin on CNS were assessed by the application of the leaves extract of Eucommia ulmoides. The extract with high percentage of astragalin had a significant effect on metabolism of mice. Moreover, it effectively prolonged the convulsion latency and diminished the convulsion rate. These results strengthen the fact that E. ulmoides has a very good hypnotic effect on CNS [49]. Astragalin also suppressed carrageenanstimulated paw edema in rats. Neural function is also reported to be improved by the use of astragalin in ischemic brain injury rat models [131].

3.4. Cardioprotective Activity. Myocardial infarction and ischemic heart failure are the leading causes of mortality in the developing countries, and their number is increasing day-by-day. They may result in reperfusion arrhythmias, myocardial stunning, and similar other cardiovascular disorders [16]. An enhanced perception of ischemia reperfusion (I/R) damage provides an innovative approach for new cardioprotective administrations [134]. Regulation of bradykinin, adenosine, opioid, adrenergic, and other G-protein connected receptors have been known to be associated with myocardial protection [135].

Certain epidemiological studies have confirmed that flavonoids stimulate cardioprotective effects against myocardial ischemia [136]. Astragalin, a bioactive flavonoid, was proved to be effective against acute I/R injury in SpragueDawley rats as its mechanism of action precedes via diminishing intracellular oxidative stress and apoptosis. The associated mechanism involves decreased expression of MDA, TNF- $\alpha$, IL-6, ROS, and Bax along with the increased ratio of GSH/GSSG, respectively [137].

3.5. Antiobesity Activity. The term "obesity" can be defined as impaired energy balance that usually results from either enhanced caloric intake and/or reduced energy consumption.
Currently, much attention has been given to several nutritional aspects that may be useful for inhibiting body fat accumulation and decreasing the risk of diseases related to obesity. In case of mammals, energy metabolism is maintained by lipolytic action in adipose tissues which is generally stimulated by some pharmacologically important lipolytic hormones such as norepinephrine, epinephrine, and catecholamines [80]. Many cellular investigations have determined that dietary polyphenols decrease viability of adipocytes and growth of preadipocytes, downregulate triglyceride accumulation and adipocyte differentiation, and induce fatty acid beta-oxidation and lipolysis [138].

Astragalin along with other known flavonoids isolated from $N$. nucifera showed inhibitory effect on diet-induced obesity and also activated $\beta$-adrenergic receptor pathway, but additional experimentation is required to fully elucidate its possible mechanism of action [80].

3.6. Antiulcer Activity. Ulcer is a chronic lesion which usually develops due to an imbalance between numerous protective and aggressive factors. Gastric ulcers being represented by repeated incidents of healing and reexacerbation contribute towards chronic inflammation which may persist for 10-20 years. It is a well-known fact that naturally occurring phenolic entities have capability to shield gastric mucosa from injury due to their cytoprotective and antioxidant features. Furthermore, flavonoids stimulate mucus secretion, block pepsinogen, prohibit $\mathrm{Ca}^{2+}$ influx, and also change GSH metabolism. Astragalin, a pharmacologically active flavonoid isolated from C. cyparissias, has been examined for its antiulcer activity. Results demonstrated that $30 \mathrm{mg} / \mathrm{kg}$ dosage of astragalin effectively decreases percentage of lesion area, total area of lesion, and ulcer index in the mice model of gastric secretion [97].

3.7. Antidiabetic Activity. Diabetes mellitus is characterized by hyperglycemia which is caused by deficit in insulin action or production [139]. Currently available antidiabetic therapeutics such as hypoglycemic drugs and insulin have limitations of their own. Natural products and herbal medicines have been suggested as one of the treatment 
TABLE 4: Cosmetic uses of astragalin.

\begin{tabular}{|c|c|c|c|c|}
\hline Assay & Organism tested & Dose/concentration & Molecular targets & References \\
\hline $\begin{array}{l}\text { Inhibition of melanin } \\
\text { secretion }\end{array}$ & Leuconostoc mesenteroides & $10 \mathrm{mM}$ & MMP- $1^{\perp}$ & [142] \\
\hline $\begin{array}{l}\text { Protection against UV } \\
\text { damage }\end{array}$ & $\begin{array}{l}\text { Mice }(\mathrm{BalB} / \mathrm{c}) \text { and human keratinocyte cells } \\
\text { (HaCaT cells) }\end{array}$ & $\begin{array}{c}2.5 \mathrm{mg} / \mathrm{kg} \text { and } \\
0.25 \mu \mathrm{M} / \mathrm{ml}\end{array}$ & $\begin{array}{l}\text { CXCL- } 1^{\downarrow} \text { and } \\
\text { CXCL- } 2^{\downarrow}\end{array}$ & [144] \\
\hline
\end{tabular}

${ }^{\downarrow}$ Downregulation; ${ }^{\perp}$ inhibition.

options for diabetes since ancient times. Naturally occurring bioactive chemical entities such as flavonoids, terpenoids, alkaloids, and phenolics have been reported as antidiabetic agents [140].

Diabetic retinopathy (DR) arises due to diabetes mellitus and is one of the most common causes of vision loss. Hyperglycemia leads to overexpression of many biological effectors such as vascular endothelial growth factor (VEGF) which is very crucial for the development of DR. Astragalin derived from A. membranaceus has beneficial effects against hyperglycemia. It helps to prevent DR by decreasing the overexpression of VEGF in cultured muller cells and alleviating the effects caused by high concentration of glucose in the blood [141].

3.8. Antifibrotic Activity. Environmental factors like air pollutants may result in considerable production of reactive oxygen species in the airways. Astragalin isolated from leaves of persimmon and green tea can be effectual in allaying ROSprompted bronchial fibrosis as it has capability to inhibit auto phagosome formation in the airways [132]. It also alleviates hepatic fibrosis by regulating PAR2 (proteaseactivated receptor 2) mechanism. AGS regulates proinflammatory cytokines namely IL-6, IL- $1 \beta$, and TNF- $\alpha$. It also attenuates the PAR2 signaling expression, and its protective effects are especially prominent in diabetic animal models [128].

3.9. Cosmetic Use. Astragalin glucosides can be used as valuable agents in cosmetics due to their important chemical characteristics. First of all, it inhibits collagenase activity. Collagenase is involved in the hydrolyzation of dermal matrix protein formation as well as wrinkle formation. Secondly, astragalin has an antioxidant activity as it alleviates the free radical species. Thirdly, astragalin controls the pigmentation in the skin caused by melanin [142]. Melanin pigment causes darkening of complexion in skin, eyes, and hair in humans. Nelumbo nucifera (lotus) contains bioactive compounds astragalin and hyperoside in the receptacles which are known to be the melanogenesis inhibitor, thus possibly decreasing the skin darkness [143]. Astragalin along with quercetin is known to possess protective effect against the UV radiations. UV radiations can make the skin of animals prone to various biological responses such as DNA damage, formation of sunburn cells, melanogenesis, photoaging, skin cancer, hyperplasia, immune suppression, and edema. UV radiations from the sun can also damage macromolecules in the epidermal layer of animals creating specific changes in the skin, for example, mutations in genes and changes in the immune system. Expression of major CXC chemokines, that is, chemokine ligand 1 (CXCL1) and chemokine ligand 2 (CXCL2), at sites of inflammation within the skin are upregulated after the exposure of skin to UV radiations. These chemokines are the potent stimulators of neutrophil activation which later on produce ROS and leads to oxidative stress. Astragalin, a major flavonoid, can be used as a barrier against UV-induced damage as it is associated with downregulation of CXCL-1 and CXCL-2 in the skin and thus can be used as a photoprotective agent [144] (Table 4).

3.10. Antiosteoporotic Activity. Osteoporosis is characterized by structural deterioration of tissues in the bone along with lower bone mass and bone fragility. The main causes of osteoporosis include estrogen deficiency, excess of glucocorticoids, and oxidative stress. Astragalin, an active compound, isolated from crude methanolic extract of the seeds of $C$. chinensis showed estrogenic activity against osteoporosis, and it is responsible for significant osteoblastic cell proliferation in UMR-106 osteoblastic cells [17].

3.11. Anticancer Activity. Currently, cancer is the second leading cause of mortality worldwide. In spite of advances in the development of new therapeutic preferences for cancer, its ratio is increasing day by day. Every year, almost 7 million people die due to cancer. Lung cancer particularly non-small cell lung cancer (NSCLC) accounts for more than $80 \%$ of deaths all around the world today. Therefore, it is necessary to discover new cheap and inexpensive drugs that can ameliorate the antitumor effects and reduce the side effects of generally recommended chemotherapy drugs [145].

Natural phytochemicals that are active constituents of medicinal plants, seeds, fruits, and herbs including polyphenols (flavonoids, terpenoids, and carotenoids) have gained significant recognizance for their potential value as therapeutic agents [146, 147]. Much research work has been conducted towards the assessment of phenolic phytochemicals as potent prophylactic agents as they can act on multiple cellular targets. The mechanistic insight into chemoprevention incorporates induction of apoptosis and cell cycle arrest or prohibition of certain cell signaling pathways mostly protein kinases $\mathrm{C}$ (PKC), glycogen synthase kinase (GSK), mitogen-activated protein kinases (MAPK), and phosphoinositide 3-kinase (PI3K) leading to abnormal AP-1, COX-2, and NF- $\kappa$ B expressions. Efficacy of chemopreventive agents revert their capacity to counteract with certain up-stream signals that leads to redox imbalances, genotoxic injury, and other situations of cellular stress. Thus, targeting damaged 
TABLE 5: Anticancer activities of astragalin in vitro and in vivo.

\begin{tabular}{|c|c|c|c|c|}
\hline Type of cancer & Cell line & Dose/concentration & Molecular targets & References \\
\hline Leukemia & HL-60 & $6 \pm 1 \mu \mathrm{M}$ & $\begin{array}{l}\text { Bax }^{\uparrow}, \text { Bcl- }^{\downarrow}{ }^{\perp}, \text { caspase- } 3 /-7^{\text {Act }} \\
\text { JNK/SAPK }, \text { and ERK } 1 / 2^{\perp}\end{array}$ & {$[15]$} \\
\hline Hepatocellular & HepG2, Huh-7, and H22 & - & $\begin{array}{l}\mathrm{HK}^{\perp} \text { and miR-125b } \\
\text { p38 } \text { MAPK }^{\downarrow} \text {, phospho-MSK1 }\end{array}$ & {$[150]$} \\
\hline Skin & HaCaT, A375P, and SK-MEL-2 & 50 and $100 \mu \mathrm{M} / \mathrm{mL}$ & $\begin{array}{c}\gamma \text {-H2AX }{ }^{\downarrow}, \text { caspase-9/-3 } 3^{\text {Act }}, \text { Bax }^{\text {Act }}, \\
\text { PARP cleavage, cyclin } \mathrm{D} 1^{\downarrow}, \mathrm{Mcl}^{\downarrow} 1^{\downarrow}, \\
\text { and SOX } 10\end{array}$ & {$[151,152]$} \\
\hline Lung & $\begin{array}{l}\text { A549, H1299, H226, H838, H23, } \\
\text { H1437, H125, H2009, and H2087 }\end{array}$ & $\begin{array}{l}5,40 \mu \mathrm{g} / \mathrm{mL}(\mathrm{A} 549) \text { and } \\
20 \mu \mathrm{g} / \mathrm{mL}(\mathrm{H} 1299)\end{array}$ & $\begin{array}{c}\text { Bax:Bcl- } 2^{\uparrow}, \text { caspase- } 9 /-3^{\uparrow}, \text { p-IKK- } \beta^{\downarrow} \text {, } \\
\text { NF- } \kappa \text { B p } 65^{\perp}, \mathrm{TNF}_{\perp} \alpha^{\perp}, \mathrm{ERK}^{\perp}-2^{\perp}, \\
\mathrm{JNK}^{\uparrow}, \mathrm{PI} 3 \mathrm{~K} / \mathrm{Akt}, \mathrm{DDH}^{\perp}, \mathrm{DRP}-1^{\downarrow}, \\
\text { pro-caspase- } 3 /-8^{\uparrow}, \text { and } \mathrm{Bax}^{\uparrow}\end{array}$ & {$[145,153]$} \\
\hline Breast & $\begin{array}{c}\text { ZR-75-1, T47D, BT20, MCF-1, and } \\
\text { MCF-7 }\end{array}$ & - & $\begin{array}{c}\mathrm{DDH}^{\perp}, \mathrm{DRP}-1^{\downarrow} \text {, pro-caspase- } 3 /-8^{\uparrow}, \\
\text { and } \mathrm{Bax}^{\uparrow}\end{array}$ & [153] \\
\hline Gastric & $\begin{array}{l}\text { AGS, SC-M1, NUGC-1, NUGC-3, } \\
\text { and KOTA-III }\end{array}$ & - & $\begin{array}{c}\mathrm{DDH}^{\perp}, \mathrm{DRP}-1^{\downarrow} \text { pro-caspase- } 3 /-8^{\uparrow}, \\
\text { and } \mathrm{Bax}^{\uparrow}\end{array}$ & {$[153]$} \\
\hline
\end{tabular}

${ }^{\uparrow}$ Upregulation; ${ }^{\downarrow}$ downregulation; ${ }^{\perp}$ inhibition.

molecules along with interrupted signal transduction pathways in cancer epitomize a rational strategy for chemoprevention, and phenolic compounds seem to be auspicious in this aspect $[147,148]$. In recent years, flavonoids have drawn developing consideration as powerful anticancer agents against various cancer types [149].

Several investigations on astragalin have explained its anticancer effect due to its promising competency to inhibit proliferation in different cancer cell lines including leukemia (HL-60) [15], hepatocellular (HepG2, Huh-7, and H22) [150], skin (HaCaT, A375P, and SK-MEL-2) [151], and lung (A549 and H1299) cancerous cells [145].

Astragalin heptaacetate (AHA), a therapeutically active flavonoid, induces apoptosis in HL-60 cells through release of cytochrome $\mathrm{c}$ into the cytosol. The associated mechanism involves activation of Bax, caspase-3/-7, and p38MAPK and intracellular ROS generation along with inhibition of cell signaling pathways JNK/SAPK and ERK $1 / 2$ [15]. Astragalin also prohibits TNF- $\alpha$-induced NF- $\kappa$ B activation in A549 and H1299 cells. Moreover, AG-triggered cell death is affiliated with increased $\mathrm{Bax}: \mathrm{Bcl}-2$ ratio and enhanced cleavage of caspase-3/-9 and PARP in conjunction with blockage of PI3K/Akt, MAPK, and ERK 1/2 signaling cascades in a timeand dose-related manner [145]. In hepatocellular carcinoma cells, astragalin (AG) significantly suppressed proliferation both in vitro in HepG2 cells and in vivo in Huh-7 (nude mice) and H22 (Kunming mice) cells via mechanistically inhibiting hexokinase 2 and upregulating miR-125b expression, respectively [150].

Astragalin can be a novel anticancer agent for the cure and prevention of UVB-stimulated actinic keratosis skin lesion by suppressing phospho-MSK1, $\gamma$-H2AX, and p38MAPK activation in a time-and dose-related manner in human $\mathrm{HaCaT}$ cells in vitro and $\mathrm{Babl} / \mathrm{c}$ mice in vivo. In another report, astragalin strongly exerted cytotoxic effects in A375P and SK-MEL-2 cancerous cells in a concentrationdependent way through induction of apoptosis. The underlying cell death mechanism involves activation of Bax and caspase-3/-9, cleavage of PARP, and downregulation of cyclin D1 and Mcl-1 along with inhibition of Sry-related HMg-Box Gene 10 (SOX10) signaling cascade [151, 152]. The reported data recommend astragalin's multitargeted activity in preference to single effect that may perform an imperative role towards developing astragalin into potential anticancer drug in future (Table 5).

\section{ADMET Profiles of Astragalin}

ADMET profiles along with biological activity spectra were performed for astragalin based on in-silico tools. The results indicate that astragalin is a potential anticancer agent which is unlikely to present any acute hazard or toxicity. Furthermore, astragalin can be absorbed by human intestines, but it is incapable of penetration to Caco-2 cells. Astragalin has been validated as a novel substrate of p-glycoprotein which is crucial for the metabolism and clearance of the compounds and for the efflux of drugs [154].

\section{Conclusions and Future Perspectives}

Astragalin, a natural flavonoid, has been isolated from various traditional medicinal plants such as Cassia alata, Moringa oleifera, Nelumbo nucifera, Cuscuta spp., Radix astragali, Morus alba, and Eucommia ulmoides. Astragalin has been reported to modulate inflammatory responses by regulating the expression of $\mathrm{NF}-\kappa \mathrm{B}$, iNOS, cytokines/chemokines (COX-2, TNF- $\alpha$, IL-10, and IL-6), MAPK signaling pathways (PGE2, IgE, IL-4, IL-5, IL-13, IL- $1 \beta$, and IL-6), and PAR2 signaling expression. It also has the capability to alleviate the production of ROS and inhibit the endotoxin-induced oxidative stress (Figure 3). Astragalin is also known to be an inhibitor of ERK-1/2 and Akt signaling; therefore, it is a significant compound against cancer proliferation. In this review paper, we have emphasized on various pharmacological properties of astragalin such as anti-inflammatory, antioxidant, neurological, cardioprotective, antidiabetic, and anticancer. Although several in vitro and in vivo investigations have demonstrated its 


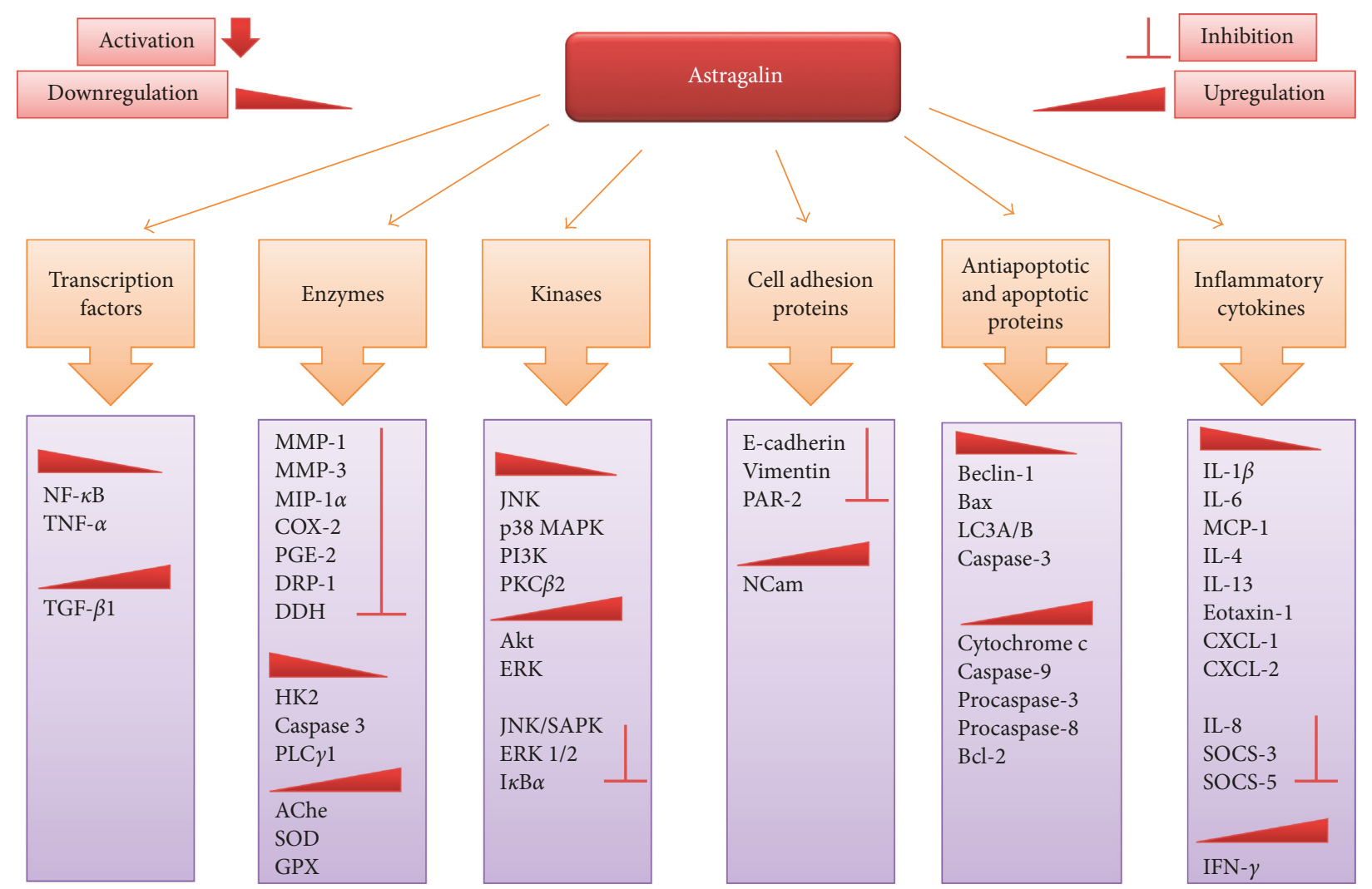

Figure 3: A diagrammatic representation of molecular targets and mechanism of action of astragalin. Astragalin has capability to modulate various transcriptional factors, enzymes, protein kinases, cell adhesion molecules, apoptotic and antiapoptotic proteins, and inflammatory cytokines resulting in anticancer, anti-inflammatory, antioxidant, and cardioprotective activities.

diversified pharmacological applications, further experimentation along with medicinal chemistry approaches and preclinical trials is still obligatory to uncover the knowledge of its biological and pharmacological applications and their associated mechanisms of actions for the treatment and prevention of several diseases.

\section{Abbreviations}

$\begin{array}{ll}\text { Ache: } & \text { Acetylcholinesterase } \\ \text { Bax: } & \text { Bcl-2 associated protein } \\ \text { Bcl-2: } & \text { B-cell lymphoma-2 } \\ \text { COX-2: } & \text { Cyclooxygenase-2 } \\ \text { CXCL-1: } & \text { Chemokine-1 } \\ \text { CXCL-2: } & \text { Chemokine-2 } \\ \text { DAF-16: } & \text { Abnormal dauer formation } \\ \text { DDH: } & \text { Dihydrodiol dehydrogenase } \\ \text { DRP-1: } & \text { Dynamin-related protein-1 }\end{array}$

E-cadherin: Epithelial cadherin

EMT: $\quad$ Epithelial to mesenchymal transition

Eotaxin-1: Eosinophil chemotactic protein

ERK: $\quad$ Extracellular signal-regulated kinase

GPX: $\quad$ Glutathione peroxide

GSH: $\quad$ Glutathione

HK2: $\quad$ Human kallikrein-related peptidase-2

IFN- $\gamma$ : Interferon gamma

IgE: $\quad$ Immunoglobin $\mathrm{E}$
IL-13: $\quad$ Interleukin-13

IL-1 $\beta$ : Interleukin-1 beta

IL-4: $\quad$ Interleukin-4

IL-6: $\quad$ Interleukin-6

IL-8: Interleukin-8

iNOS: $\quad$ Inducible nitric oxide synthase

$\mathrm{I} \kappa \mathrm{B} \alpha: \quad$ Inhibitor of kappa B alpha

JNK: $\quad$ c-Jun N-terminal kinase

LC3A/B: Microtubule-associated protein 1 light chain 3A/B

MAPK: Mitogen-activated protein kinase

Mcl-1: $\quad$ Myeloid cell leukemia 1

MCP-1: $\quad$ Monocyte chemoattractant protein-1

MIP-1 $\alpha$ : Macrophage inflammatory protein 2-alpha

miR-125: MicroRNA-125

MMP: $\quad$ Mitochondrial membrane potential

MMP-1: $\quad$ Matrix metalloproteinase-1

MMP-3: $\quad$ Matrix metalloproteinase-3

NCam: Neutral cell adhesion molecule

NO: $\quad$ Nitric oxide

PAR2: $\quad$ Protease-activated receptor 2

PGE2: $\quad$ Prostaglandin E2

PI3K: $\quad$ Phosphoinositide-3

PKC $\beta 2$ : $\quad$ Protein kinase $C$ beta-2

PLC $\gamma$ 1: $\quad$ Phosphoinositide phospholipase C $\gamma 1$

SAPK: $\quad$ Stress-activated protein kinase

SOCS-3: $\quad$ Suppressor of cytokine signaling 3 
SOCS-5: $\quad$ Suppressor of cytokine signaling 5

SOD: $\quad$ Superoxide dismutase

SOD: $\quad$ Superoxide dismutase

SOX10: $\quad$ Sry-related HMg-Box gene 10

TGF- $\beta 1$ : Transforming growth factor beta 1

TLR-4: $\quad$ Toll-like receptor 4

TNF- $\alpha$ : Tumor necrosis factor alpha.

\section{Conflicts of Interest}

The authors declare that there are no conflicts of interest.

\section{Acknowledgments}

This study was supported by the research grant from The Nagai Foundation, Tokyo, Japan (NFT-R4-2017 and NFTR4-2018) and TWAS-COMSTECH Research Grant (no. 17180 RG/PHA/AS_C). The authors would also like to thank Higher Education Commission (HEC), Pakistan, for providing access to related papers from various journals.

\section{References}

[1] D. J. Newman and G. M. Cragg, "Natural products as sources of new drugs over the 30 years from 1981 to 2010," Journal of Natural Products, vol. 75, no. 75, pp. 311-335, 2012.

[2] D. G. Kingston, "Modern natural products drug discovery and its relevance to biodiversity conservation," Journal of Natural Products, vol. 74, no. 74, pp. 496-511, 2011.

[3] C. Veeresham, "Natural products derived from plants as a source of drugs," Journal of Advanced Pharmaceutical Technology and Research, vol. 3, no. 3, pp. 200-201, 2012.

[4] C. Katiyar, A. Gupta, S. Kanjilal, and S. Katiyar, "Drug discovery from plant sources: an integrated approach," Ayu, vol. 33, no. 33, pp. 10-19, 2012.

[5] A. L. Harvey, "Natural products in drug discovery," Drug Discovery Today, vol. 13, no. 13, pp. 894-901, 2008.

[6] Y. Luo, R. E. Cobb, and H. Zhao, "Recent advances in natural product discovery," Current Opinion in Biotechnology, vol. 30, no. 30, pp. 230-237, 2014.

[7] A. Rasul, F. M. Millimouno, W. Ali Eltayb, M. Ali, J. Li, and X. Li, "Pinocembrin: a novel natural compound with versatile pharmacological and biological activities," BioMed Research International, vol. 2013, Article ID 379850, 9 pages, 2013.

[8] J. Hong, "Role of natural product diversity in chemical biology," Current Opinion in Chemical Biology, vol. 15, no. 15, pp. 350-354, 2011.

[9] O. I. Aruoma, M. Grootveld, and T. Bahorun, "Free radicals in biology and medicine: from inflammation to biotechnology,” BioFactors, vol. 27, no. 27, pp. 1-3, 2006.

[10] J. K. Prasain and S. Barnes, "Metabolism and bioavailability of flavonoids in chemoprevention: current analytical strategies and future prospectus," Molecular Pharmaceutics, vol. 4, no. 4, pp. 846-864, 2007.

[11] J. P. Spencer, "Flavonoids: modulators of brain function?," British Journal of Nutrition, vol. 99, no. 1, pp. ES60-ES77, 2008.

[12] M. Kotani, M. Matsumoto, A. Fujita et al., "Persimmon leaf extract and astragalin inhibit development of dermatitis and IgE elevation in NC/Nga mice," Journal of Allergy and Clinical Immunology, vol. 106, no. 106, pp. 159-166, 2000.
[13] L. Bitis, S. Kultur, G. Melikoglu, N. Ozsoy, and A. Can, "Flavonoids and antioxidant activity of Rosa agrestis leaves," Natural Product Research, vol. 24, no. 24, pp. 580-589, 2010.

[14] Y. H. Kim, Y. J. Choi, M. K. Kang et al., “Astragalin inhibits allergic inflammation and airway thickening in ovalbuminchallenged mice," Journal of Agricultural and Food Chemistry, vol. 65, no. 65, pp. 836-845, 2017.

[15] O. Burmistrova, J. Quintana, J. G. Diaz, and F. Estevez, "Astragalin heptaacetate-induced cell death in human leukemia cells is dependent on caspases and activates the MAPK pathway," Cancer Letters, vol. 309, no. 309, pp. 71-77, 2011.

[16] K. R. Bainey and P. W. Armstrong, "Clinical perspectives on reperfusion injury in acute myocardial infarction," American Heart Journal, vol. 167, no. 167, pp. 637-645, 2014.

[17] L. Yang, Q. Chen, F. Wang, and G. Zhang, "Antiosteoporotic compounds from seeds of Cuscuta chinensis," Journal of Ethnopharmacology, vol. 135, no. 135, pp. 553-560, 2011.

[18] S. Donnapee, J. Li, X. Yang et al., "Cuscuta chinensis Lam.: a systematic review on ethnopharmacology, phytochemistry and pharmacology of an important traditional herbal medicine," Journal of Ethnopharmacology, vol. 157, no. 157, pp. 292-308, 2014.

[19] S. Saito, G. Silva, R. X. Santos, G. Gosmann, C. Pungartnik, and M. Brendel, "Astragalin from Cassia alata induces DNA adducts in vitro and repairable DNA damage in the yeast Saccharomyces cerevisiae," International Journal of Molecular Sciences, vol. 13, no. 13, pp. 2846-2862, 2012.

[20] J. Pei, P. Dong, T. Wu et al., "Metabolic engineering of Escherichia coli for astragalin biosynthesis," Journal of Agricultural and Food Chemistry, 2016, In Press.

[21] X. Z. Huang, L. X. Tan, K. Gu, and C. Li, "Studies on chemical constituents from leaves of Acer truncatum," China Journal of Chinese Materia Medica, vol. 32, no. 32, pp. 1544-1546, 2007.

[22] J. T. Han, M. H. Bang, O. K. Chun, D. O. Kim, C. Y. Lee, and N. I. Baek, "Flavonol glycosides from the aerial parts of Aceriphyllum rossii and their antioxidant activities," Archives of Pharmacal Research, vol. 27, no. 27, pp. 390-395, 2004.

[23] H. Kato, W. Li, M. Koike, Y. Wang, and K. Koike, "Phenolic glycosides from Agrimonia pilosa," Phytochemistry, vol. 71, no. 71, pp. 1925-1929, 2010.

[24] A. Ivanova, B. Mikhova, H. Najdenski, I. Tsvetkova, and I. Kostova, "Chemical composition and antimicrobial activity of wild garlic Allium ursinum of Bulgarian origin," Natural Product Communications, vol. 4, no. 4, pp. 10591062, 2009.

[25] K. T. Lee, J. H. Choi, D. H. Kim et al., "Constituents and the antitumor principle of Allium victorialis var. platyphyllum," Archives of Pharmacal Research, vol. 24, no. 24, pp. 44-50, 2001.

[26] H. C. Chiang, Y. J. Lo, and F. J. Lu, "Xanthine oxidase inhibitors from the leaves of Alsophila spinulosa (Hook) Tryon," Journal of Enzyme Inhibition, vol. 8, no. 8, pp. 61-71, 1994.

[27] Y. Zhang, C. Liu, Z. Zhang, J. Wang, G. Wu, and S. Li, "Comprehensive separation and identification of chemical constituents from Apocynum venetum leaves by highperformance counter-current chromatography and high performance liquid chromatography coupled with mass spectrometry," Journal of Chromatography B, vol. 878, no. 878, pp. 3149-3155, 2010.

[28] N. T. Huong, N. K. Cu, T. V. Quy, C. Zidorn, M. Ganzera, and H. Stuppner, "A new phenylpropanoid glycoside from 
Jasminum subtriplinerve Blume," Journal of Asian Natural Products Research, vol. 10, no. 10, pp. 1035-1038, 2008.

[29] I. Krasteva, S. Platikanov, S. Nikolov, and M. Kaloga, "Flavonoids from Astragalus hamosus," Natural Product Research, vol. 21, no. 21, pp. 392-395, 2007.

[30] P. V. Kiem, C. V. Minh, H. T. Huong, J. J. Lee, and Y. H. Kim, "Caesaldecan, a cassane diterpenoid from the leaves of Caesalpinia decapetala," Chemical and Pharmaceutical Bulletin, vol. 53, no. 53, pp. 428-430, 2005.

[31] H. Ahmed, A. Moawad, A. Owis, S. AbouZid, and O. Ahmed, "Flavonoids of Calligonum polygonoides and their cytotoxicity," Pharmaceutical Biology, vol. 54, no. 54, pp. 21192126, 2016.

[32] D. W. Chung and S. B. Lee, "Novel synthesis of leucoside by enzymatic hydrolysis of tea seed extract," Journal of the Science of Food and Agriculture, vol. 93, no. 93, pp. 362-367, 2013.

[33] H. B. Lee, E. K. Kim, S. J. Park, S. G. Bang, T. G. Kim, and D. W. Chung, "Isolation and anti-inflammatory effect of astragalin synthesized by enzymatic hydrolysis of tea seed extract," Journal of the Science of Food and Agriculture, vol. 91, no. 91, pp. 2315-2321, 2011.

[34] H. B. Lee, E. K. Kim, S. J. Park, S. G. Bang, T. G. Kim, and D. W. Chung, "Isolation and characterization of nicotiflorin obtained by enzymatic hydrolysis of two precursors in tea seed extract," Journal of Agricultural and Food Chemistry, vol. 58, no. 58, pp. 4808-4813, 2010.

[35] Z. M. Luo, T. J. Ling, L. X. Li et al., "A new norisoprenoid and other compounds from Fuzhuan brick tea," Molecules, vol. 17, no. 17, pp. 3539-3546, 2012.

[36] W. S. Feng, Z. Y. Hao, X. K. Zheng, and H. X. Kuang, "Chemical constituents from leaves of Celastrus gemmatus Loes," Acta Pharmaceutica Sinica, vol. 42, no. 42, pp. 625630, 2007.

[37] N. X. Nhiem, B. H. Tai, T. H. Quang et al., "A new ursanetype triterpenoid glycoside from Centella asiatica leaves modulates the production of nitric oxide and secretion of TNF- $\alpha$ in activated RAW 264.7 cells," Bioorganic and Medicinal Chemistry Letters, vol. 21, no. 21, pp. 1777-1781, 2011.

[38] H. Van Oanh, P. X. Sinh, N. T. An et al., "A new rearranged abietane diterpene and other constituents from Clerodendrum philipinum," Natural Product Communications, vol. 4, no. 4, pp. 323-325, 2009.

[39] F. Calzada, R. Cedillo-Rivera, and R. Mata, "Antiprotozoal activity of the constituents of Conyza filaginoides," Journal of Natural Products, vol. 64, no. 64, pp. 671-673, 2001.

[40] M. Yoshikawa, H. Shimada, M. Saka, S. Yoshizumi, J. Yamahara, and H. Matsuda, "Medicinal foodstuffs. V. Moroheiya. (1): absolute stereostructures of corchoionosides $\mathrm{A}, \mathrm{B}$, and $\mathrm{C}$, histamine release inhibitors from the leaves of Vietnamese Corchorus olitorius L. (Tiliaceae)," Chemical and Pharmaceutical Bulletin, vol. 45, no. 45, pp. 464-469, 1997.

[41] M. Ye, Y. Yan, and D. A. Guo, "Characterization of phenolic compounds in the Chinese herbal drug Tu-Si-Zi by liquid chromatography coupled to electrospray ionization mass spectrometry," Rapid Communications in Mass Spectrometry, vol. 19, no. 19, pp. 1469-1484, 2005.

[42] H. Guo and J. Li, "Flavonoids of Cuscuta australis R. Br," China Journal of Chinese Materia Medica, vol. 22, no. 22, pp. 38-39, 1997.

[43] X. He, W. Yang, M. Ye, Q. Wang, and D. Guo, "Differentiation of Cuscuta chinensis and Cuscuta australis by HPLCDAD-MS analysis and HPLC-UV quantitation," Planta Medica, vol. 77, no. 77, pp. 1950-1957, 2011.
[44] J. H. Lee, C. H. Ku, N. I. Baek, S. H. Kim, H. W. Park, and D. K. Kim, "Phytochemical constituents from Diodia teres," Archives of Pharmacal Research, vol. 27, no. 27, pp. 40-43, 2004.

[45] C. Braunberger, M. Zehl, J. Conrad et al., "LC-NMR, NMR, and LC-MS identification and LC-DAD quantification of flavonoids and ellagic acid derivatives in Drosera peltata," Journal of Chromatography B, vol. 932, no. 932, pp. 111-116, 2013.

[46] G. A. Cordell, R. L. Lyon, H. H. Fong, P. S. Benoit, and N. R. Farnsworth, "Biological and phytochemical investigations of Dianthus barbatus cv. "China Doll" (Caryophyllaceae)," Lloydia, vol. 40, no. 40, pp. 361-363, 1977.

[47] H. Y. Kim, B. H. Moon, H. J. Lee, and D. H. Choi, "Flavonol glycosides from the leaves of Eucommia ulmoides O. with glycation inhibitory activity," Journal of Ethnopharmacology, vol. 93, no. 93, pp. 227-230, 2004.

[48] J. Cheng, Y. Y. Zhao, Y. X. Cui, and T. M. Cheng, "Studies on flavonoids from leave of Eucommia ulmoides Oliv," China Journal of Chinese Materia Medica, vol. 25, no. 25, pp. 284-286, 2000.

[49] X. Li, Z. Tang, D. Fei, Y. Liu, M. Zhang, and S. Liu, "Evaluation of the sedative and hypnotic effects of astragalin isolated from Eucommia ulmoides leaves in mice," Natural Product Research, vol. 31, no. 31, pp. 2072-2076, 2017.

[50] E. T. Elema, J. Schripsema, and T. M. Malingre, "Flavones and flavonol glycosides from Eupatorium cannabinum L," Pharmaceutisch Weekblad. Scientific Edition, vol. 11, no. 11, pp. 161-164, 1989.

[51] S. H. Qian, N. Y. Yang, J. A. Duan, L. H. Yuan, and L. J. Tian, "Study on the flavonoids of Eupatorium lindleyanum," China Journal of Chinese Materia Medica, vol. 29, no. 29, pp. 50-52, 2004.

[52] J. Zhang, X. Li, L. Ren, C. Fang, and F. Wang, "Chemical constituents from Exochorda racemosa," China Journal of Chinese Materia Medica, vol. 36, no. 36, pp. 1198-1201, 2011.

[53] Q. Xie, L. Ding, Y. Wei, and Y. Ito, "Determination of major components and fingerprint analysis of Flaveria bidentis (L.) Kuntze," Journal of Chromatographic Science, vol. 52, no. 52, pp. 252-257, 2014.

[54] Y. Wei, Q. Xie, D. Fisher, and I. A. Sutherland, "Separation of patuletin-3-O-glucoside, astragalin, quercetin, kaempferol and isorhamnetin from Flaveria bidentis (L.) Kuntze by elution-pump-out high-performance counter-current chromatography," Journal of chromatography A, vol. 1218, pp. 6206-6211, 2011.

[55] Y. Yang, Y. Zhao, D. Gu et al., "Separation of the minor flavonols from Flos Gossypii by high-speed countercurrent chromatography," Journal of Liquid Chromatography and Related Technologies, vol. 33, no. 33, pp. 1502-1515, 2010.

[56] Z. G. Tai, X. Q. Yang, L. Cai, W. J. Sun, Z. T. Ding, and Y. B. Yang, "Studies on the chemical constituents from the aerial parts of Gladiolus gandavensis," Journal of Chinese Medicinal Materials, vol. 33, no. 33, pp. 1257-1259, 2010.

[57] D. M. Biondi, C. Rocco, and G. Ruberto, "Dihydrostilbene derivatives from Glycyrrhiza glabra leaves," Journal of Natural Products, vol. 68, no. 68, pp. 1099-1102, 2005.

[58] S. S. Jia, C. M. Ma, Y. H. Li, and J. H. Hao, "Glycosides of phenolic acid and flavonoids from the leaves of Glycyrrhiza uralensis Ficsh," Acta Pharmaceutica Sinica, vol. 27, no. 27, pp. 441-444, 1992.

[59] K. Algariri, K. Y. Meng, I. J. Atangwho et al., "Hypoglycemic and anti-hyperglycemic study of Gynura procumbens leaf 
extracts," Asian Pacific Journal of Tropical Biomedicine, vol. 3, no. 3, pp. 358-366, 2013.

[60] A. Trute and A. Nahrstedt, "Identification and quantitative analysis of phenolic compounds from the dry extract of Hedera helix," Planta Medica, vol. 63, no. 63, pp. 177-179, 1997.

[61] F. Calzada and A. D. Alanis, "Additional antiprotozoal flavonol glycosides of the aerial parts of Helianthemum glomeratum," Phytotherapy Research, vol. 21, no. 21, pp. 78-80, 2007.

[62] Y. L. Ren and J. S. Yang, "Study on chemical constituents of Hemistepta lyrata Bunge," Acta Pharmaceutica Sinica, vol. 36, no. 36, pp. 746-749, 2001.

[63] M. Heinaaho, J. Pusenius, and R. Julkunen-Tiitto, "Effects of different organic farming methods on the concentration of phenolic compounds in sea buckthorn leaves," Journal of Agricultural and Food Chemistry, vol. 54, no. 54, pp. 76787685, 2006.

[64] J. G. Luo and L. Y. Kong, "Study on flavonoids from leaf of Ipomoea batatas," China Journal of Chinese Materia Medica, vol. 30, no. 30, pp. 516-518, 2005.

[65] Q. H. Qu, L. Zhang, H. Bao, J. H. Zhang, X. J. You, and J. X. Wang, "Chemical constituents of flavonoids from flowers of Koelreuteria paniculata," Journal of Chinese Medicinal Materials, vol. 34, no. 34, pp. 1716-1719, 2011.

[66] N. Bernaert, D. Wouters, L. De Vuyst et al., "Antioxidant changes of leek (Allium ampeloprasum var. porrum) during spontaneous fermentation of the white shaft and green leaves," Journal of the Science of Food and Agriculture, vol. 93, no. 93, pp. 2146-2153, 2013.

[67] D. C. Ren, N. Y. Yang, S. H. Qian, N. Xie, X. M. Zhou, and J. A. Duan, "Chemical study on aerial parts of Ligusticum chuanxiong," China Journal of Chinese Materia Medica, vol. 32, no. 32, pp. 1418-1420, 2007.

[68] M. Xiao, N. Cao, J. J. Fan, Y. Shen, and Q. Xu, "Studies on flavonoids from the leaves of Lindera aggregata," Journal of Chinese Medicinal Materials, vol. 34, no. 34, pp. 62-64, 2011.

[69] H. Ye and J. Yu, "The preliminary studies on antioxidation of three kinds of flavoniods from Litsea coreana," Journal of Chinese Medicinal Materials, vol. 27, no. 27, pp. 113-115, 2004.

[70] K. Y. Jung, S. R. Oh, S. H. Park et al., “Anti-complement activity of tiliroside from the flower buds of Magnolia fargesii," Biological and Pharmaceutical Bulletin, vol. 21, no. 21, pp. 1077-1078, 1998.

[71] B. Vongsak, P. Sithisarn, and W. Gritsanapan, "Simultaneous HPLC quantitative analysis of active compounds in leaves of Moringa oleifera Lam," Journal of Chromatographic Science, vol. 52, no. 52, pp. 641-645, 2014.

[72] K. Doi, T. Kojima, M. Makino, Y. Kimura, and Y. Fujimoto, "Studies on the constituents of the leaves of Morus alba L," Chemical and Pharmaceutical Bulletin, vol. 49, no. 49, pp. 151-153, 2001.

[73] M. Sugiyama, T. Katsube, A. Koyama, and H. Itamura, "Varietal differences in the flavonol content of mulberry (Morus spp.) leaves and genetic analysis of quercetin 3-(6malonylglucoside) for component breeding," Journal of Agricultural and Food Chemistry, vol. 61, no. 61, pp. 91409147, 2013.

[74] J. He, Y. Feng, H. Z. Ouyang et al., “A sensitive LC-MS/MS method for simultaneous determination of six flavonoids in rat plasma: application to a pharmacokinetic study of total flavonoids from mulberry leaves," Journal of Pharmaceutical and Biomedical Analysis, vol. 84, no. 84, pp. 189-195, 2013.
[75] J. Choi, H. J. Kang, S. Z. Kim, T. O. Kwon, S. I. Jeong, and S. I. Jang, "Antioxidant effect of astragalin isolated from the leaves of Morus alba L. against free radical-induced oxidative hemolysis of human red blood cells," Archives of Pharmacal Research, vol. 36, no. 36, pp. 912-917, 2013.

[76] Y. Zou, S. Liao, W. Shen et al., "Phenolics and antioxidant activity of mulberry leaves depend on cultivar and harvest month in Southern China," International Journal of Molecular Sciences, vol. 13, no. 13, pp. 16544-16553, 2012.

[77] Y. Tao, Y. Zhang, Y. Cheng, and Y. Wang, "Rapid screening and identification of alpha-glucosidase inhibitors from mulberry leaves using enzyme-immobilized magnetic beads coupled with HPLC/MS and NMR," Biomedical Chromatography, vol. 27, no. 27, pp. 148-155, 2013.

[78] S. Y. Kim, J. J. Gao, W. C. Lee, K. S. Ryu, K. R. Lee, and Y. C. Kim, "Antioxidative flavonoids from the leaves of Morus alba," Archives of Pharmacal Research, vol. 22, no. 22, pp. 81-85, 1999.

[79] Y. Ranarivelo, A. L. Skaltsounis, M. Andriantsiferana, and F. Tillequin, "Glycosides from Mussaenda arcuata Lam. ex Poiret leaves," Annales Pharmaceutiques Francaises, vol. 48, no. 48, pp. 273-277, 1990.

[80] E. Ohkoshi, H. Miyazaki, K. Shindo, H. Watanabe, A. Yoshida, and H. Yajima, "Constituents from the leaves of Nelumbo nucifera stimulate lipolysis in the white adipose tissue of mice," Planta Medica, vol. 73, no. 73, pp. 1255-1259, 2007.

[81] N. Tian, Z. Liu, J. Huang, G. Luo, S. Liu, and X. Liu, "Isolation and preparation of flavonoids from the leaves of Nelumbo nucifera Gaertn by preparative reversed-phase high performance liquid chromatography," Chinese Journal of Chromatography, vol. 25, no. 25, pp. 88-92, 2007.

[82] X. L. Zhao, Z. M. Wang, X. J. Ma, W. G. Jing, and A. Liu, "Chemical constituents from leaves of Nelumbo nucifera," China Journal of Chinese Materia Medica, vol. 38, no. 38, pp. 703-708, 2013.

[83] S. Xu, Y. Sun, F. Jing, W. Duan, J. Du, and X. Wang, "Separation and purification of flavones from Nelumbo nucifera Gaertn. by silica gel chromatography and highspeed counter-current chromatography," Chinese Journal of Chromatography, vol. 29, no. 29, pp. 1244-1248, 2011.

[84] S. Deng, Z. Deng, Y. Fan et al., "Isolation and purification of three flavonoid glycosides from the leaves of Nelumbo nucifera (Lotus) by high-speed counter-current chromatography," Journal of chromatography B, vol. 877, no. 877, pp. 2487-2492, 2009.

[85] H. H. Barakat, A. M. El-Mousallamy, A. M. Souleman, and S. Awadalla, "Flavonoids of Ochradenus baccatus," Phytochemistry, vol. 30, no. 30, pp. 3777-3779, 1991.

[86] C. Je Ma, W. J. Jung, K. Y. Lee, Y. C. Kim, and S. H. Sung, "Calpain inhibitory flavonoids isolated from Orostachys japonicus," Journal of Enzyme Inhibition and Medicinal Chemistry, vol. 24, no. 24, pp. 676-679, 2009.

[87] M. Matsumoto, M. Kotani, A. Fujita et al., "Oral administration of persimmon leaf extract ameliorates skin symptoms and transepidermal water loss in atopic dermatitis model mice, NC/Nga," British Journal of Dermatology, vol. 146, no. 146, pp. 221-227, 2002.

[88] Y. L. Xue, T. Miyakawa, Y. Hayashi et al., "Isolation and tyrosinase inhibitory effects of polyphenols from the leaves of persimmon, Diospyros kaki," Journal of Agricultural and Food Chemistry, vol. 59, no. 59, pp. 6011-6017, 2011.

[89] K. Kameda, T. Takaku, H. Okuda et al., "Inhibitory effects of various flavonoids isolated from leaves of persimmon on 
angiotensin-converting enzyme activity," Journal of Natural Products, vol. 50, no. 50, pp. 680-683, 1987.

[90] Z. Ma, T. Piao, Y. Wang, and J. Liu, "Astragalin inhibits IL$1 \beta$-induced inflammatory mediators production in human osteoarthritis chondrocyte by inhibiting NF- $\mathrm{KB}$ and MAPK activation," International Immunopharmacology, vol. 25, no. 25, pp. 83-87, 2015.

[91] F. Li, W. Wang, Y. Cao et al., "Inhibitory effects of astragalin on lipopolysaccharide-induced inflammatory response in mouse mammary epithelial cells," Journal of Surgical Research, vol. 192, no. 192, pp. 573-581, 2014.

[92] F. Li, D. Liang, Z. Yang et al., "Astragalin suppresses inflammatory responses via down-regulation of NF- $\kappa \mathrm{B}$ signaling pathway in lipopolysaccharide-induced mastitis in a murine model," International Immunopharmacology, vol. 17, no. 17, pp. 478-482, 2013.

[93] K. Skalicka-Wozniak, J. Szypowski, and K. Glowniak, "HPLC analysis of kaempherol and quercetin derivatives isolated by different extraction techniques from plant matrix," Journal of AOAC International, vol. 94, no. 94, pp. 17-21, 2011.

[94] J. M. Laparra, R. P. Glahn, and D. D. Miller, “Assessing potential effects of inulin and probiotic bacteria on $\mathrm{Fe}$ availability from common beans (Phaseolus vulgaris L.) to Caco-2 cells," Journal of Food Science, vol. 74, no. 74, pp. H40-H46, 2009.

[95] Y. Takeda, N. Isai, T. Masuda et al., "Phlomisflavosides A and B, new flavonol bisglycosides from Phlomis spinidens," Chemical and Pharmaceutical Bulletin, vol. 49, no. 49, pp. 1039-1041, 2001.

[96] C. Agyare, M. Lechtenberg, A. Deters, F. Petereit, and A. Hensel, "Ellagitannins from Phyllanthus muellerianus (Kuntze) Exell.: Geraniin and furosin stimulate cellular activity, differentiation and collagen synthesis of human skin keratinocytes and dermal fibroblasts," Phytomedicine, vol. 18, no. 18, pp. 617-624, 2011.

[97] L. C. Klein-Junior, J. R. Santin, M. Lemos et al., "Role of gastric mucus secretion, oxinitrergic system and sulfhydryl groups on the gastroprotection elicited by Polygala cyparissias (Polygalaceae) in mice," Journal of Pharmacy and Pharmacology, vol. 65, no. 65, pp. 767-776, 2013.

[98] I. Calis, A. Kuruuzum, L. O. Demirezer, O. Sticher, W. Ganci, and P. Ruedi, "Phenylvaleric acid and flavonoid glycosides from Polygonum salicifolium," Journal of Natural Products, vol. 62, no. 62, pp. 1101-1105, 1999.

[99] M. A. Olszewska and A. Kwapisz, "Metabolite profiling and antioxidant activity of Prunus padus L. flowers and leaves," Natural Product Research, vol. 25, no. 25, pp. 1115-1131, 2011.

[100] M. Olszewska, "High-performance liquid chromatographic identification of flavonoid monoglycosides from Prunus serotina ehrh," Acta Poloniae Pharmaceutica, vol. 62, no. 62, pp. 435-441, 2005.

[101] M. Krauze-Baranowska, P. Sowinski, A. Kawiak, and B. Sparzak, "Flavonoids from Pseudotsuga menziesii," Journal of Biosciences, vol. 68, no. 68, pp. 87-96, 2013.

[102] H. J. Kwon and Y. D. Park, "Determination of astragalin and astragaloside content in Radix astragali using highperformance liquid chromatography coupled with pulsed amperometric detection," Journal of Chromatography A, vol. 1232, pp. 212-217, 2012.

[103] J. Jian and Z. Wu, "Influences of traditional Chinese medicine on non-specific immunity of Jian Carp (Cyprinus carpio var. Jian)," Fish and Shellfish Immunology, vol. 16, no. 16, pp. 185-191, 2004.
[104] G. Li, T. Gao, J. Wen, R. Yang, C. Yu, and S. Zhang, "A research on the quality of radix Astragali," China Journal of Chinese Materia Medica, vol. 17, no. 17, pp. 454-456, 1992.

[105] Y. Ding, H. T. Nguyen, E. M. Choi, K. Bae, and Y. H. Kim, "Rhusonoside A, a new megastigmane glycoside from Rhus sylvestris, increases the function of osteoblastic MC3T3-E1 cells," Planta Medica, vol. 75, no. 75, pp. 158-162, 2009.

[106] C. Yang, F. Li, X. Zhang, L. Wang, Z. Zhou, and M. Wang, "Phenolic antioxidants from Rosa soulieana flowers," Natural Product Research, vol. 27, no. 27, pp. 2055-2058, 2013.

[107] T. B. Nguelefack, F. H. Mbakam, L. A. Tapondjou et al., "A dimeric triterpenoid glycoside and flavonoid glycosides with free radical-scavenging activity isolated from Rubus rigidus var. camerunensis," Archives of Pharmacal Research, vol. 34, no. 34, pp. 543-550, 2011.

[108] H. Q. Wang, C. Y. Zhao, and R. Y. Chen, "Studies on chemical constituents from leaves of Sapium sebiferum," China Journal of Chinese Materia Medica, vol. 32, no. 32, pp. 1179-1181, 2007.

[109] M. S. Kamel, K. Ohtani, H. A. Hasanain, M. H. Mohamed, R. Kasai, and K. Yamasaki, "Monoterpene and pregnane glucosides from Solenostemma argel," Phytochemistry, vol. 53, no. 53, pp. 937-940, 2000.

[110] P. Apati, P. J. Houghton, and A. Kery, "HPLC investigation of antioxidant components in Solidago herba," Acta Pharmaceutica Hungarica, vol. 74, no. 74, pp. 223-231, 2004.

[111] M. A. Olszewska and P. Michel, "Activity-guided isolation and identification of free radical-scavenging components from various leaf extracts of Sorbus aria (L.) Crantz," Natural Product Research, vol. 26, no. 26, pp. 243-254, 2012.

[112] W. Xiang, R. T. Li, Y. L. Mao et al., "Four new prenylated isoflavonoids in Tadehagi triquetrum," Journal of Agricultural and Food Chemistry, vol. 53, no. 53, pp. 267-271, 2005.

[113] G. Shen, S. R. Oh, B. S. Min et al., "Phytochemical investigation of Tiarella polyphylla," Archives of Pharmacal Research, vol. 31, no. 31, pp. 10-16, 2008.

[114] S. Hosoi, E. Shimizu, K. Ohno et al., "Structural studies of zoospore attractants from Trachelospermum jasminoides var. pubescens: taxifolin 3-O-glycosides," Phytochemical Analysis, vol. 17, no. 17, pp. 20-24, 2006.

[115] H. Aishan, M. Baba, N. Iwasaki, H. Kuang, and T. Okuyama, "The constituents of Urtica cannabina used in Uighur medicine," Pharmaceutical Biology, vol. 48, no. 48, pp. 577-583, 2010.

[116] R. R. Majinda, M. Motswaledi, R. D. Waigh, and P. G. Waterman, "Phenolic and antibacterial constituents of Vahlia capensis," Planta Medica, vol. 63, no. 63, pp. 268-270, 1997.

[117] A. N. Singab, D. T. Youssef, E. Noaman, and S. Kotb, "Hepatoprotective effect of flavonol glycosides rich fraction from Egyptian Vicia calcarata Desf. against CCl4-induced liver damage in rats," Archives of Pharmacal Research, vol. 28, no. 28, pp. 791-798, 2005.

[118] S. Apers, Y. Huang, S. Van Miert et al., "Characterisation of new oligoglycosidic compounds in two Chinese medicinal herbs," Phytochemical Analysis, vol. 13, no. 13, pp. 202-206, 2002.

[119] U. Weiss, "Inflammation," Nature, vol. 454, no. 454, p. 427, 2008.

[120] I. Sarfraz, A. Rasul, F. Jabeen et al., "Fraxinus: a plant with versatile pharmacological and biological activities," Evidence-Based Complementary and Alternative Medicine, vol. 2017, Article ID 4269868, 12 pages, 2017. 
[121] J. Walker, K. V. Reichelt, K. Obst et al., "Identification of an anti-inflammatory potential of Eriodictyon angustifolium compounds in human gingival fibroblasts," Food and Function, vol. 7, no. 7, pp. 3046-3055, 2016.

[122] L. W. Soromou, N. Chen, L. Jiang et al., "Astragalin attenuates lipopolysaccharide-induced inflammatory responses by down-regulating NF- $\mathrm{BB}$ signaling pathway," Biochemical and Biophysical Research Communications, vol. 419, no. 419, pp. 256-261, 2012.

[123] E. J. Choi, S. Lee, J. R. Chae, H. S. Lee, C. D. Jun, and S. H. Kim, "Eupatilin inhibits lipopolysaccharide-induced expression of inflammatory mediators in macrophages," Life Sciences, vol. 88, no. 88, pp. 1121-1126, 2011.

[124] W. Zhang, X. Lu, W. Wang et al., "Inhibitory effects of emodin, thymol, and astragalin on leptospira interrogansinduced inflammatory response in the uterine and endometrium epithelial cells of mice," Inflammation, vol. 40, no. 40, pp. 666-675, 2017.

[125] H. Inaba, M. Tagashira, D. Honma et al., "Identification of hop polyphenolic components which inhibit prostaglandin E2 production by gingival epithelial cells stimulated with periodontal pathogen," Biological and Pharmaceutical Bulletin, vol. 31, no. 31, pp. 527-530, 2008.

[126] J. Liu, Y. Cheng, X. Zhang et al., "Astragalin attenuates allergic inflammation in a murine asthma model," Inflammation, vol. 38, no. 38, pp. 2007-2016, 2015.

[127] M. S. Kim and S. H. Kim, "Inhibitory effect of astragalin on expression of lipopolysaccharide-induced inflammatory mediators through NF- $\mathrm{kB}$ in macrophages," Archives of Pharmacal Research, vol. 34, no. 34, pp. 2101-2107, 2011.

[128] Z. Wang, Q. Li, M. Xiang et al., "Astragaloside alleviates hepatic fibrosis function via PAR2 signaling pathway in diabetic rats," Cellular Physiology and Biochemistry, vol. 41, no. 41, pp. 1156-1166, 2017.

[129] I. H. Cho, J. H. Gong, M. K. Kang et al., "Astragalin inhibits airway eotaxin-1 induction and epithelial apoptosis through modulating oxidative stress-responsive MAPK signaling," BMC Pulmonary Medicine, vol. 14, no. 14, p. 122, 2014.

[130] H. Li, R. Shi, F. Ding et al., "Astragalus polysaccharide suppresses 6-hydroxydopamine-induced neurotoxicity in Caenorhabditis elegans," Oxidative Medicine and Cellular Longevity, vol. 2016, p. 4856761, 2016.

[131] L. Yan and Q. H. Zhou, "Study on neuroprotective effects of astragalan in rats with ischemic brain injury and its mechanisms," Chinese Journal of Applied Physiology, vol. 28, no. 28, pp. 373-377, 2012.

[132] I. H. Cho, Y. J. Choi, J. H. Gong, D. Shin, M. K. Kang, and Y. H. Kang, "Astragalin inhibits autophagy-associated airway epithelial fibrosis,” Respiratory Research, vol. 16, no. 16, p. 51, 2015.

[133] A. Wasik and L. Antkiewicz-Michaluk, "The mechanism of neuroprotective action of natural compounds," Pharmacological Reports, vol. 69, no. 69, pp. 851-860, 2017.

[134] A. Habertheuer, A. Kocher, G. Laufer et al., "Cardioprotection: a review of current practice in global ischemia and future translational perspective," BioMed Research International, vol. 2014, Article ID 325725, 11 pages, 2014.

[135] K. Tanaka, J. R. Kersten, and M. L. Riess, "Opioid-induced cardioprotection," Current Pharmaceutical Design, vol. 20, no. 20, pp. 5696-5705, 2014.

[136] L. Testai, "Flavonoids and mitochondrial pharmacology: A new paradigm for cardioprotection," Life Sciences, vol. 135, no. 135, pp. 68-76, 2015.
[137] D. Qu, J. Han, H. Ren et al., "Cardioprotective effects of astragalin against myocardial ischemia/reperfusion injury in isolated rat heart," Oxidative Medicine and Cellular Longevity, vol. 2016, Article ID 8194690, 11 pages, 2016.

[138] S. Wang, N. Moustaid-Moussa, L. Chen et al., "Novel insights of dietary polyphenols and obesity," Journal of Nutritional Biochemistry, vol. 25, no. 25, pp. 1-18, 2014.

[139] U. Alam, O. Asghar, S. Azmi, and R. A. Malik, "General aspects of diabetes mellitus," Handbook of Clinical Neurology, vol. 126, no. 126, pp. 211-222, 2014.

[140] M. Jung, M. Park, H. C. Lee, Y. H. Kang, E. S. Kang, and S. K. Kim, "Antidiabetic agents from medicinal plants," Current Medicinal Chemistry, vol. 13, no. 13, pp. 1203-1218, 2006.

[141] M. Ke, X. Q. Hu, J. Ouyang, B. Dai, and Y. Xu, "The effect of astragalin on the VEGF production of cultured Muller cells under high glucose conditions," Bio-Medical Materials and Engineering, vol. 22, no. 22, pp. 113-119, 2012.

[142] G. E. Kim, H. K. Kang, E. S. Seo et al., "Glucosylation of the flavonoid, astragalin by Leuconostoc mesenteroides B-512FMCM dextransucrase acceptor reactions and characterization of the products," Enzyme and Microbial Technology, vol. 50, no. 50, pp. 50-56, 2012.

[143] S. Y. Jung, W. S. Jung, H. K. Jung et al., "The mixture of different parts of Nelumbo nucifera and two bioactive components inhibited tyrosinase activity and melanogenesis," Journal of Cosmetic Science, vol. 65, no. 65, pp. 377-388, 2014.

[144] A. Svobodova, J. Psotova, and D. Walterova, "Natural phenolics in the prevention of UV-induced skin damage. A review," Biomedical Papers of the Medical Faculty of the University Palacky, Olomouc, Czechoslovakia, vol. 147, no. 147, pp. 137-145, 2003.

[145] M. Chen, F. Cai, D. Zha et al., "Astragalin-induced cell death is caspase-dependent and enhances the susceptibility of lung cancer cells to tumor necrosis factor by inhibiting the NF- $\kappa \mathrm{B}$ pathway," Oncotarget, vol. 8, no. 8, pp. 26941-26958, 2017.

[146] M. Rasool, A. Malik, A. Manan et al., "Roles of natural compounds from medicinal plants in cancer treatment: structure and mode of action at molecular level," Medicinal Chemistry, vol. 11, no. 11, pp. 618-628, 2015.

[147] V. S. Neergheen, T. Bahorun, E. W. Taylor, L. S. Jen, and O. I. Aruoma, "Targeting specific cell signaling transduction pathways by dietary and medicinal phytochemicals in cancer chemoprevention," Toxicology, vol. 278, no. 278, pp. 229$241,2010$.

[148] S. Jafari, S. Saeidnia, and M. Abdollahi, "Role of natural phenolic compounds in cancer chemoprevention via regulation of the cell cycle," Current Pharmaceutical Biotechnology, vol. 15, no. 15, pp. 409-421, 2014.

[149] J. Sun, F. Li, Y. Zhao et al., "LZ-207, a newly synthesized flavonoid, induces apoptosis and suppresses inflammation-related colon cancer by inhibiting the NFкB signaling pathway," PloS One, vol. 10, no. 10, article e0127282, 2015.

[150] W. Li, J. Hao, L. Zhang, Z. Cheng, X. Deng, and G. Shu, "Astragalin reduces hexokinase 2 through increasing miR$125 \mathrm{~b}$ to inhibit the proliferation of hepatocellular carcinoma cells in vitro and in vivo," Journal of Agricultural and Food Chemistry, vol. 65, no. 65, pp. 5961-5972, 2017.

[151] O. H. You, E. A. Shin, H. Lee et al., "Apoptotic effect of astragalin in melanoma skin cancers via activation of caspases and inhibition of Sry-related HMg-box gene 10," Phytotherapy Research, vol. 31, no. 31, pp. 1614-1620, 2017. 
[152] J. Zhang, N. Li, K. Zhang et al., “Astragalin attenuates UVB radiation-induced actinic keratosis formation," Anti-Cancer Agents in Medicinal Chemistry, 2017, In Press.

[153] Y. Y. Chiang, S. L. Wang, C. L. Yang et al., "Extracts of Koelreuteria henryi Dummer induce apoptosis and autophagy by inhibiting dihydrodiol dehydrogenase, thus enhancing anticancer effects," International Journal of Molecular Medicine, vol. 32, no. 32, pp. 577-584, 2013.

[154] O. Ammar, "In silico pharmacodynamics, toxicity profile and biological activities of the Saharan medicinal plant Limoniastrum feei," Brazilian Journal of Pharmaceutical Sciences, vol. 53, no. 53, pp. 1-10, 2017. 

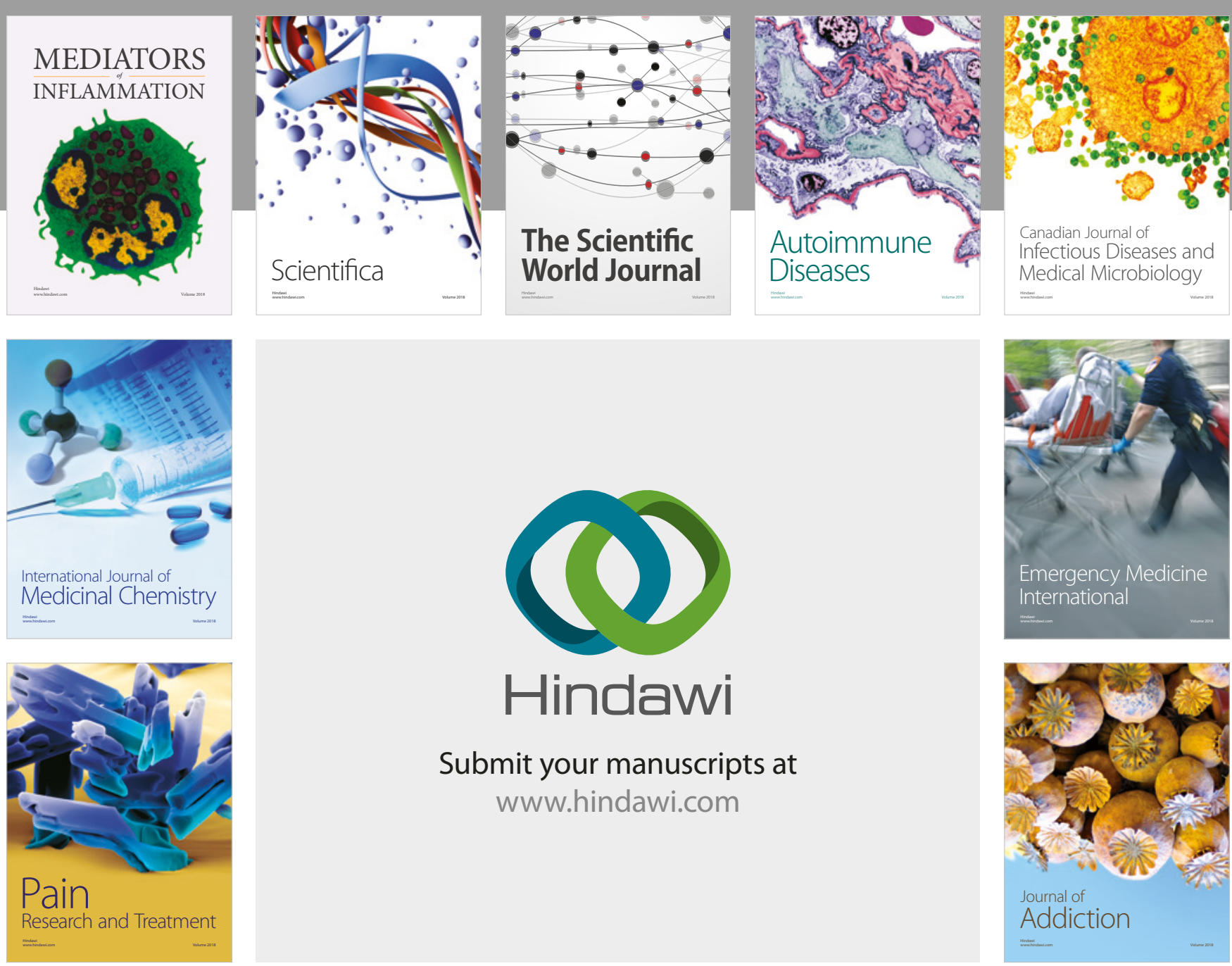

Canadian Journal of
Infectious Diseases and Medical Microbiology

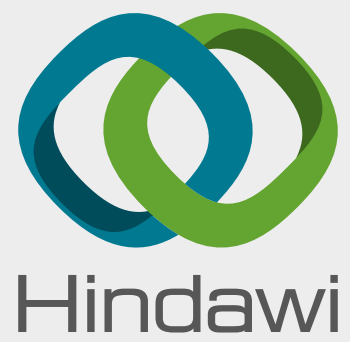

Submit your manuscripts at

www.hindawi.com
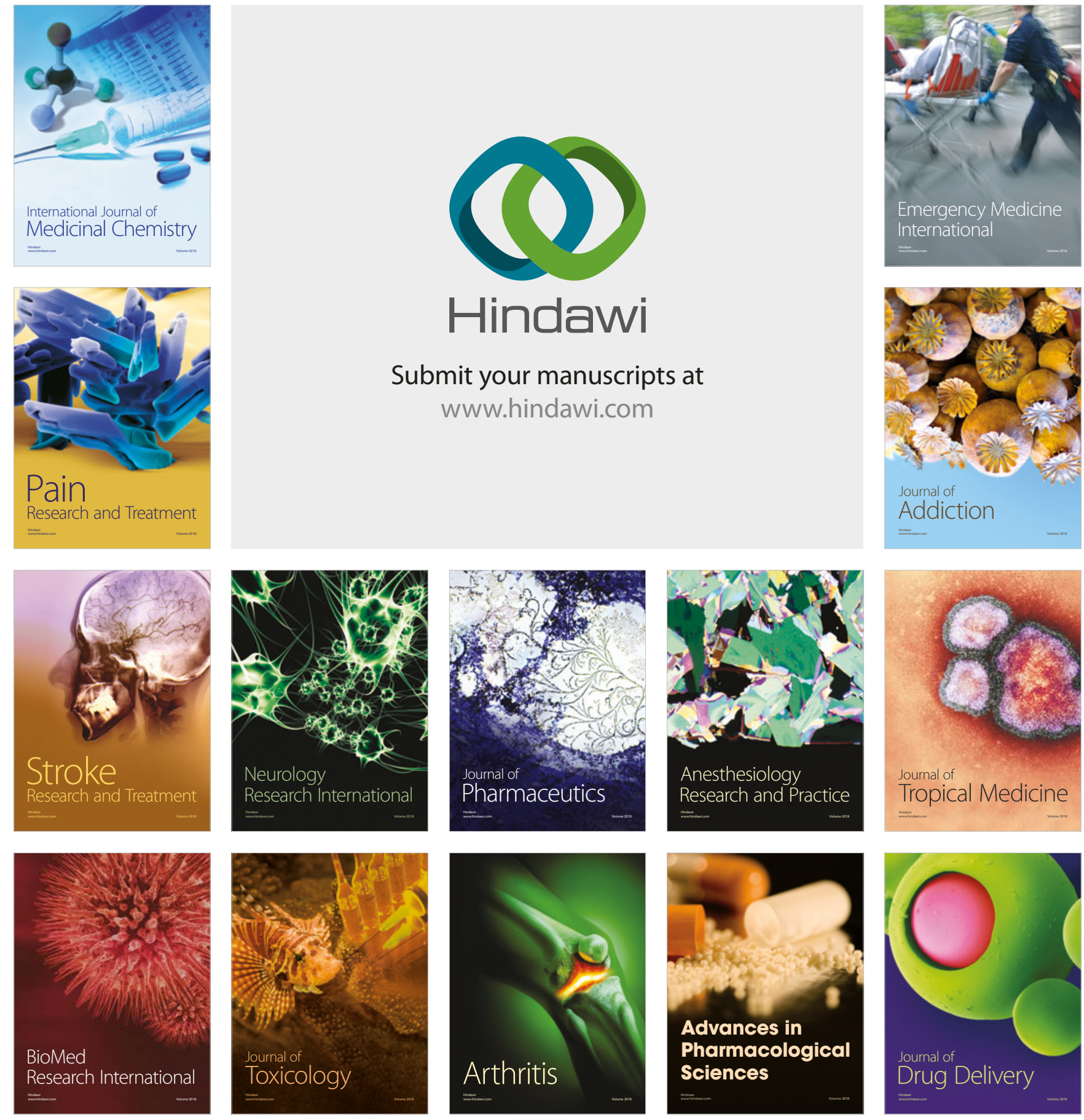